\title{
Younger Dryas and early Holocene subsistence in the northern Great Basin: multiproxy analysis of coprolites from the Paisley Caves, Oregon, USA
}

\author{
John C. Blong ${ }^{1}$ (D) $\cdot$ Martin E. Adams ${ }^{2} \cdot$ Gabriel Sanchez $^{3} \cdot$ Dennis L. Jenkins $^{4} \cdot$ lan D. Bull ${ }^{5} \cdot$ Lisa-Marie Shillito $^{1}$
}

Received: 22 November 2019 / Accepted: 14 July 2020 / Published online: 28 August 2020

(C) The Author(s) 2020

\begin{abstract}
Younger Dryas and early Holocene Western Stemmed Tradition occupants of the northern Great Basin appear to have practiced a broad-based subsistence strategy including the consumption of a wide variety of small animal and plant resources. However, much of our evidence for human diet and land use during this period comes from dry cave and rockshelter sites where it can be challenging to distinguish plant and small animal remains deposited as a result of human versus nonhuman activity. This study presents new direct evidence for Younger Dryas and early Holocene human diet in the northern Great Basin through multiproxy analysis of nine human coprolites from the Paisley Caves, Oregon, USA. The evidence indicates that Western Stemmed Tradition occupants consumed plants, small mammals, fish, and insects, including direct evidence for consumption of whole rodents and several types of beetle. Occupation of the caves occurred during the summer and fall by individuals foraging on wetland, sagebrush grassland, and riparian ecological landscapes suggesting geographical and seasonal variability in land-use patterns during the Younger Dryas and early Holocene periods. This research suggests that Western Stemmed Tradition settlement patterns were seasonally centered on productive valley bottom lakes and wetlands but also included forays to a variety of ecological landscapes. The results highlight the importance of plant and small animal resources in the human diet during the terminal Pleistocene settlement of North America and contribute to debates about the process of the peopling of the Americas.
\end{abstract}

Keywords Western Stemmed Tradition $\cdot$ Hunter-gatherer diet $\cdot$ Younger Dryas $\cdot$ Great Basin $\cdot$ Coprolite

This article is part of the Topical Collection on Coprolite Research: Archaeological and Paleoenvironmental Potentials

Electronic supplementary material The online version of this article (https://doi.org/10.1007/s12520-020-01160-9) contains supplementary material, which is available to authorized users.

John C. Blong

John.Blong@newcastle.ac.uk

1 School of History, Classics and Archaeology, Newcastle University, Newcastle upon Tyne, UK

2 Paleoinsect Research, Clatskanie, OR, USA

3 Department of Anthropology, Michigan State University, East Lansing, MI, USA

4 Museum of Natural and Cultural History, University of Oregon, Eugene, OR, USA

5 Organic Geochemistry Unit, School of Chemistry, University of Bristol, Bristol, UK

\section{Introduction}

The Great Basin of North America offers informative case studies of regional hunter-gatherer subsistence and landuse adaptations during the first several millennia of human occupation of the Americas. Great Basin sites dating to the Younger Dryas (YD) cold period $(12,900-$ 11,700 cal BP) and early Holocene (EH) warm period (11,700-8900 cal BP) typically contain Western Stemmed Tradition (WST) projectile points and related technology (Beck and Jones 1997; Jenkins et al. 2012; Smith and Barker 2017; Smith et al. 2020). Preserved organic remains at a few widely separated WST sites in the Great Basin suggest a perplexing array of settlementsubsistence scenarios. YD/EH occupants may have had a broad-based subsistence strategy including a wide variety of small animal and plant resources centered on productive valley bottom lacustrine settings and surrounding 
grasslands (Beck and Jones 1997; Bedwell 1973; Madsen 2007; Smith and Barker 2017; Hockett 2015; Hockett et al. 2017; Jenkins et al. 2016; Smith and Barker 2017), or, they may have maintained much higher mobility and a more restricted diet focused on large-bodied mammals (Elston and Zeanah 2002; Elston et al. 2014; Jones et al. 2003).

Addressing the debate about the nature of WST subsistence and land-use patterns has been hampered by the paucity of direct evidence of human diets from this period (Smith and Barker 2017). The most direct method for understanding past human dietary decisions is through the analysis of coprolites (Battillo 2019; Bryant 1974b; Callen 1963; Riley 2008, 2010). Here we present a multiproxy analysis of pollen, phytolith, macrobotanical, faunal, and insect remains from nine YD/EH human coprolites recovered at the Paisley Caves in south central Oregon (Fig. 1), providing new evidence for WST human diets. This evidence is evaluated within the broader record of $\mathrm{YD} / \mathrm{EH}$ subsistence at the Paisley Caves and used to test WST subsistence and land-use models. The results provide support for a broad-based subsistence strategy employed during summer/fall occupations of the caves during the WST period. This research highlights the importance of plant and small animal resources in the human diet during the terminal Pleistocene settlement of North America. The results of this study inform broader debates about specialized large mammal versus generalized and regionally variable subsistence strategies during this time.

\section{YD/EH archaeology of the northern Great Basin}

WST occupations at the Paisley Caves have been dated as early as $13,000 \mathrm{cal}$ BP and offer a robust data set to evaluate early subsistence-settlement systems in the northern Great Basin (Jenkins et al. 2012, 2013). WST toolkits in the region are typically made from locally available high-quality toolstone - obsidian, in particular - that was often transported across hundreds of kilometers suggesting high mobility (Jones et al. 2003; Smith 2010). Technology was flexible and maintainable, characteristics typically associated with high mobility (Elston and Zeanah 2002; Elston et al. 2014). WST lithic assemblages lack heavy ground stone milling equipment and are instead dominated by formally flaked tools (bifacial and unifacial) and large projectile points presumed to function as tools to hunt and process large-bodied mammals (Elston and Zeanah 2002). These attributes suggest highly mobile landuse strategies and an overall reliance on a narrow set of highranked food resources (Beck and Jones 1997; Elston et al. 2014; Goebel et al. 2011). However, WST cave and rockshelter sites containing stratified, well-dated, and wellpreserved $\mathrm{YD} / \mathrm{EH}$ deposits provide evidence for a diverse diet of large-, medium-, and small-bodied mammals; birds; fishes; insects; seeds; and roots (Aikens et al. 2011; Grayson 1988; Hockett and Jenkins 2013; Jenkins et al. 2013, 2016; Kennedy and Smith 2016; Smith and Barker 2017).

WST sites in the northern Great Basin are typically associated with valley bottom wetland and riparian zones (Smith and Barker 2017). There is strong evidence for textile

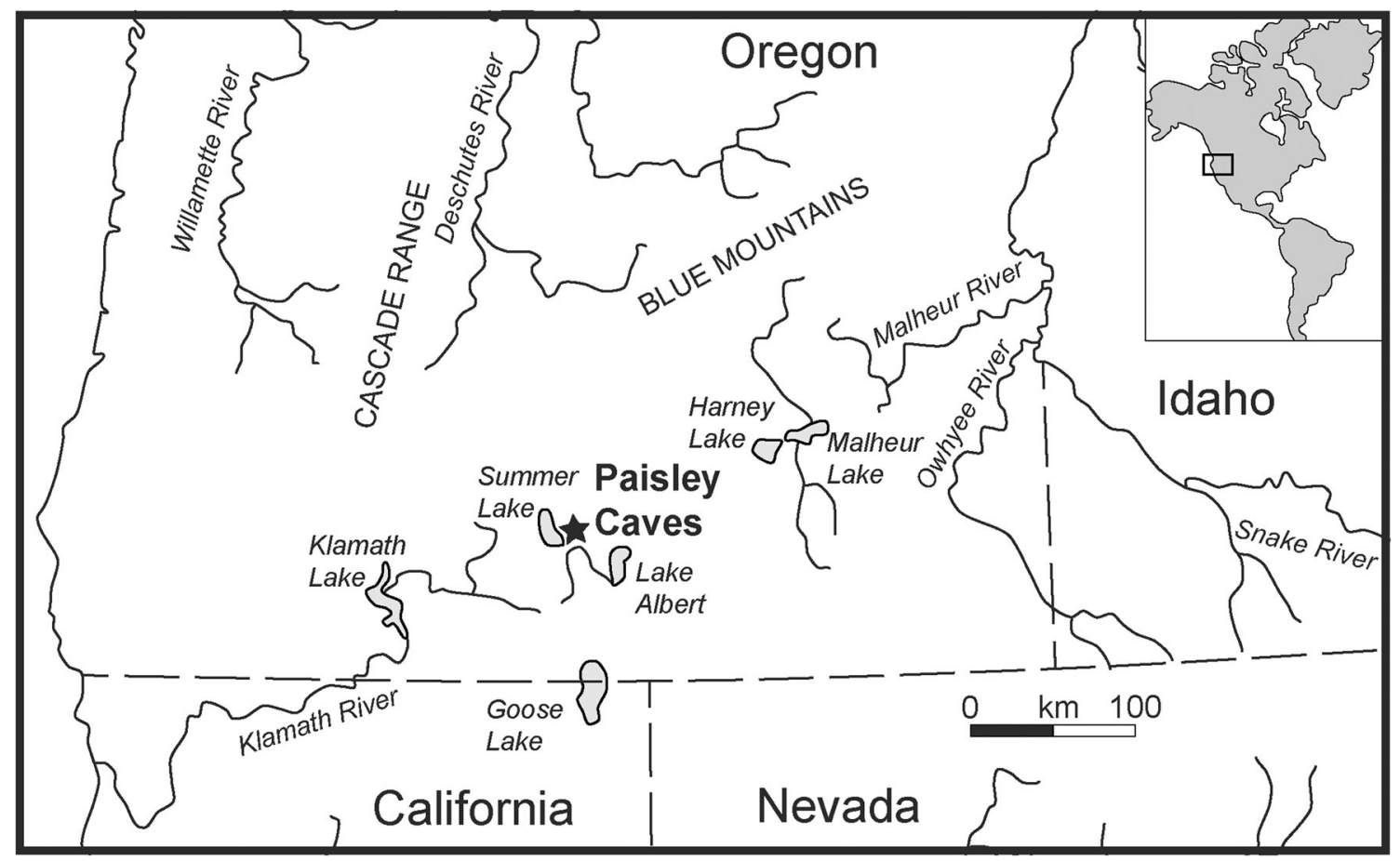

Fig. 1 Map showing the location of the Paisley Caves in southcentral Oregon 
production requiring raw materials from wetland and sagebrush steppe ecological zones (e.g., tule and sagebrush bark) and investment in production (Smith and Barker 2017). These characteristics suggest WST occupants of the region lived in longer-term residential camps near wetlands for part or most of the year (Elston et al. 2014; Madsen 2007; Smith and Barker 2017). However, WST sites are also found in midelevation and upland locations, including upland rock art sites in well-known root grounds (Middleton et al. 2014; Ricks and Cannon 1993; Smith and Barker 2017). The density of archaeological deposits at some EH sites suggests they may have functioned as residential camps; however, the paucity of storage or structural features at most sites indicates they were most commonly ephemeral occupations (Smith and Barker 2017). These characteristics suggest that WST hunter-gatherers in the northern Great Basin were not always tethered to lowelevation wetland habitats and may indicate a wide-ranging seasonally variable settlement-subsistence strategy (Aikens et al. 2011, p. 71; Jones et al. 2003; Smith 2010).

The archaeological record of the northern Great Basin largely mirrors that of the broader Great Basin. WST lithic toolkits across the Great Basin provide evidence for highly mobile land-use strategies (Graf 2001; Jones et al. 2003, 2012; Smith 2011). Blood protein residue analysis of a WST projectile from western Utah and two handstones from Paisley Caves provide evidence for hunting of Proboscidean and Equus prey (Duke 2015; Jenkins et al. 2013). However, well-preserved deposits from YD/EH occupations at cave and rockshelter sites like Smith Creek Cave (Bryan 1980), Bonneville Estates Rockshelter (Hockett 2007, 2015; Rhode and Louderback 2007), Hogup Cave (Aikens 1970; Fry 1970, 1976; Harper and Alder 1970; Herzog and Lawlor 2016), and Danger Cave (Fry 1970, 1976, 1978; Grayson 1988; Jennings 1957; Parmalee 1988; Rhode and Louderback 2007; Rhode et al. 2006) contain plant, insect, large animal, and small animal remains suggesting a broad-based subsistence strategy, although these often are not unequivocally linked to human occupation (e.g., Goebel et al. 2011; Grayson 1988; Rhode and Louderback 2007). Despite the growing body of data supporting broad-based diets and seasonally variable land use during the WST period, we have very little direct dietary evidence to inform current debates. Coprolite studies in the Great Basin provide direct evidence for WST subsistence; however, there are a limited number of sites with coprolites from this period (Cummings et al. 2007; Fry 1970, 1976; Napton 1997).

Determining the nature of terminal Pleistocene subsistence-settlement strategies in the Great Basin is important because it links to broader debates about the process of initial human settlement of North America. The first widely distributed archaeological complex in North America was long thought to be the Clovis complex, primarily identified by the presence of lanceolate-shaped fluted projectile points associated with radiocarbon dates ca. 13,250-12,700 cal BP (Bradley et al. 2010; Collins 1999; Waters and Stafford Jr 2007; Waters et al. 2011). Clovis assemblages are often associated with now-extinct Pleistocene large mammal remains, especially mammoth (Mammuthus sp.), and are thought to represent highly mobile large mammal hunters moving into previously unoccupied parts of North America at the end of the Pleistocene (Haynes Jr. 1966; Haynes 2002; Kelly and Todd 1988; Surovell and Waguespack 2008; Waguespack and Surovell 2003).

Fluted points are found in the Great Basin; however, they have not been found in well-dated contexts. The few radiocarbon dates associated with fluted technology in the Great Basin indicate an age range of 13,100-8400 cal BP (Beck and Jones 2013; Goebel and Keene 2014; Smith et al. 2020). Great Basin fluted points exhibit considerable variability in form suggesting they are younger than those east of the Rocky Mountain divide (Beck and Jones 1997, 2013; Davis et al. 2012). Sites like the Paisley Caves, Cooper's Ferry, and the Debra L. Friedkin site present evidence that WST assemblages in western North America are co-eval with and possibly even older than Clovis assemblages (Davis et al. 2019; Jenkins et al. 2012; Waters et al. 2018). This evidence suggests that the initial occupation of western North America may not be related to the widespread Clovis archaeological complex-instead, the WST may represent initial settlement by huntergatherers linked to Pacific coastal-adapted settlers (Davis et al. 2012; Madsen et al. 2015). Understanding WST subsistence-settlement systems, then, is crucial for understanding the process of the initial settlement of North America.

\section{Paisley Caves site background and environmental context}

The YD was a period of rapid climate fluctuation in North America (Rasmussen et al. 2014). During this time, temperatures cooled, effective moisture increased in the northern Great Basin, and lakes and wetlands covered many valley bottoms including near the Paisley Caves in the Chewaucan Basin (Grayson 2011; Jenkins et al. 2016). Paleoenvironmental studies at the Paisley Caves indicate sagebrush steppe vegetation on the surrounding landscape with possible eastward expansion of forested areas from the Cascade Mountains into the grasslands of the northern Great Basin (Beck et al. 2018; Saban and Jenkins 2013; Saban 2015). The EH saw a shift toward a warmer, more arid climate in the northern Great Basin, with the summer insolation maximum peaking at 11,000 cal BP. During this time, many valley bottom lakes shrank, forming extensive wetland marshes that were productive habitats for fish, waterfowl, and mammals (Grayson 2011; Minckley et al. 2004). Paleoenvironmental research at the Paisley Caves supports a transition to more xeric taxa with 
subalpine conifer and marsh communities nearby (Beck et al. 2018; Saban and Jenkins 2013; Saban 2015).

The Paisley Caves are one of the most extensively studied sites in the northern Great Basin, with well-dated cultural sequences in three caves $(1,2,5)$ spanning the terminal Pleistocene through historic period (Jenkins et al. 2013; Jenkins et al. 2016). This study focuses on the WST record from caves 2 and 5. Five primary lithostratigraphic units (LU) have been defined in caves 2 and 5 representing approximately 16,000 years of eolian, volcanic, biogenic, and anthropogenic deposition (Jenkins 2007; Jenkins et al. 2012; Jenkins et al. 2016) (Fig. 2). WST material in cave 5 is concentrated in LU 2, consisting of loose to indurated organic sandy deposits associated with dates spanning the latter part of the BøllingAllerød through the EH (Jenkins et al. 2012, Jenkins et al. 2016). WST material in cave 2 is most commonly associated with the distinctive "botanical lens" cultural horizon ephemerally expressed at the base of LU 3 and its contact with underlying LU 2 (Jenkins et al. 2016). The botanical lens is marked by matted sagebrush (Artemisia sp.) twigs and shredded bark, 5-8 cm thick where undisturbed, deposited between 12,320 and $11,960 \mathrm{cal} \mathrm{BP}$ (Jenkins et al. 2016). The botanical lens contains remarkably well-preserved evidence of human occupation including hearth features; pronghorn (Antilocapra americana), white-tailed jackrabbit (Lepus townsendii), and marmot (Marmota sp.) hair, hide, and bone fragments; fish, waterfowl, greater sage grouse (Centrocerus urophasianus) and insect remains including Mormon cricket (Anabrus simplex), bed bug (Cimex sp.), and spinose ear tick (Otobius megnini) (Adams and Jenkins 2017; Adams and Jenkins
2020; Hockett et al. 2017). Numerous organic artifacts include cordage, rope, basketry, and wood tools. Lithic assemblages from caves 2 and 5 include WST projectile points, bifaces, scrapers, flake knives, edge-modified flakes, cores, and grooved scoria abraders (Jenkins et al. 2012, Jenkins et al. 2016). Human activity at the Paisley Caves during the YD/ EH is currently interpreted to represent short-term seasonal occupations when local resources were most abundant, for example, during spring and late summer/fall (Jenkins et al. 2016; Kennedy 2018).

Previous research at the Paisley Caves has characterized YD/EH subsistence using plant and animal remains recovered in dry- or wet-screened sediments from cultural deposits in the caves (Hockett et al. 2017; Kennedy 2018). These studies provide important evidence that people with WST toolkits occupying the caves consumed small animal, plant, and insect foods. However, the caves were also inhabited by many nonhuman species over the millennia, and it can be challenging to distinguish organic materials resulting from human subsistence from those that are the result of noncultural processes such as animal nesting and carnivore activity (Andrews 1990; Sauqué et al. 2018). Excavations at the Paisley Caves have produced a substantial assemblage of human coprolites from YD/EH contexts. Coprolites commonly contain preserved plant and animal macrofossil and microfossil remains that can be used to reconstruct dietary choices made by the individual (Callen and Martin 1969; Fry 1976; Reinhard and Bryant Jr 2008). This high-resolution record of human diet is well-suited to addressing the relative importance of small animal and plant food resources and the nature of WST

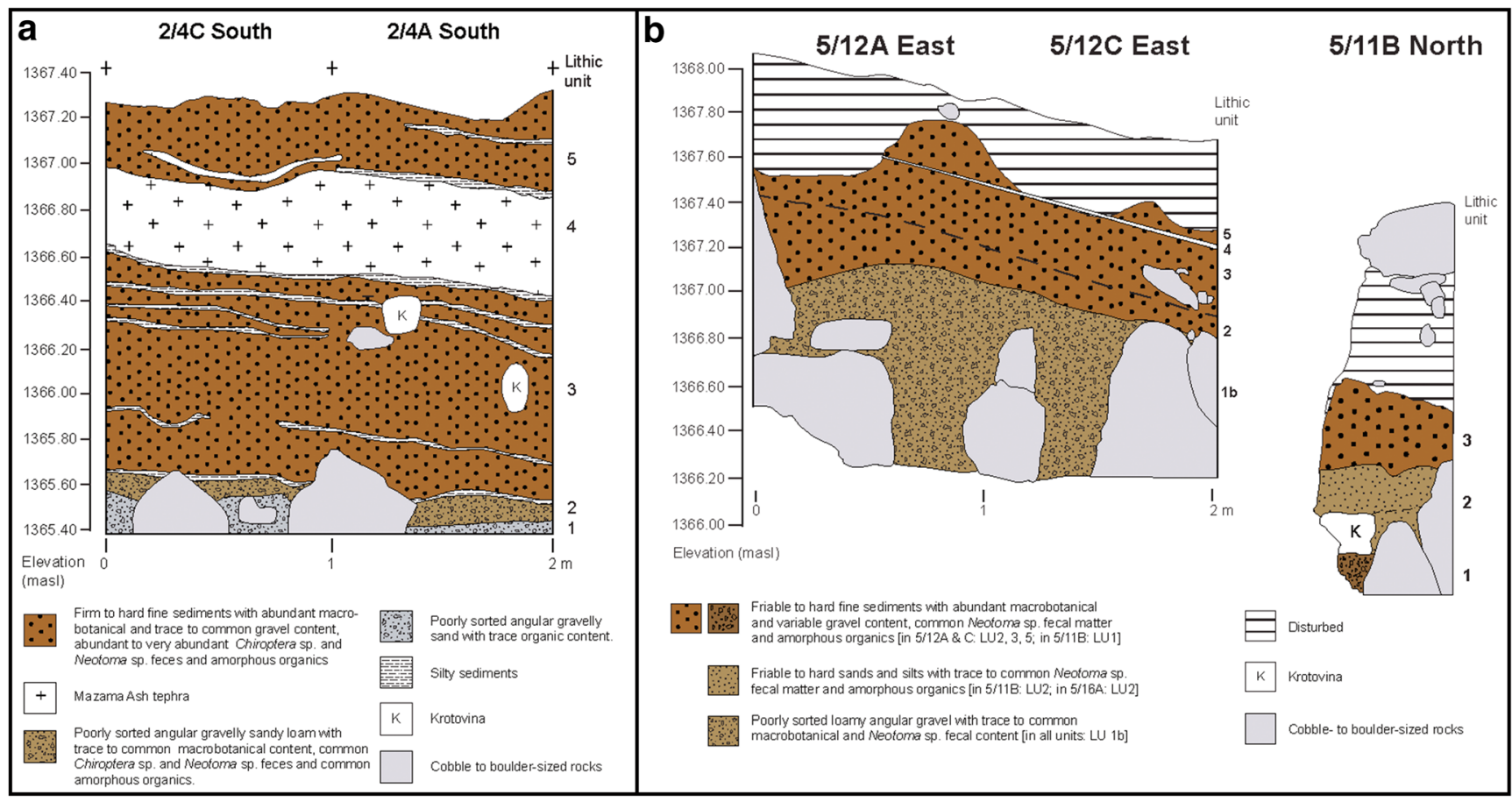

Fig. 2 Stratigraphic profiles showing lithic units defined in Paisley Cave 2 (a) and Paisley Cave 5 (b). Images redrawn from Jenkins et al. 2012 
seasonal land-use patterns as expressed at the Paisley Caves. It provides important information for investigating the broader nature of YD/EH subsistence-settlement systems in the northern Great Basin.

Here, we present a new study of coprolites from Paisley Caves combining multiproxy (plant and animal macrofossil, pollen, and phytolith) analyses of nine probable human coprolites recovered from YD/EH contexts in Paisley Cave 2 and 5. Multiproxy coprolite studies are critical because they provide multiple lines of direct evidence for human dietary choices, and offer the possibility of constraining seasonal models of occupation (Milner 1999; Monks 1981; Shillito et al. 2020a).

\section{Materials and methods}

\section{Coprolite sampling and morphological description}

Each coprolite was photographed and described following Jouy-Avantin et al. (2003). Coprolites were initially chosen for this study based on physical characteristics suggesting human origin (following Bryant 1974b). These determinations were made with the caveat that physical characteristics alone cannot always accurately identify the species of animal that deposited the coprolite (Bryant 1974b; Chame 2003; Reinhard and Bryant Jr 2008; Shillito et al. 2011; Shillito et al. 2020a). The sampling process is summarized in Fig. 3 and the coprolites are shown in Fig. 4. Coprolites were cut along the long axis using a sterile disposable scalpel and one half of each was employed in this study. The other half has been retained in the sample archive. Collecting a subsample representing the entire length of the coprolite is preferred because macro- and microfossils can be unequally distributed along the length of a coprolite as a by-product of consuming different meals (Beck et al. 2019; Martin and Sharrock 1964). The exception to this methodology occurred with samples 57, 195, and 215, which consisted of already-fragmented coprolite material; for these three samples, a discrete fragment was collected for our analysis to preserve as much intact material as possible for future research.

For most subsamples, the exterior layer of coprolite material was scraped off using a sterile scalpel to remove potential contaminants, thereby creating an "interior" coprolite sample. The interior material was processed for pollen, phytolith, and plant and animal macrofossils as described in the following sections. However, it was not possible to secure an interior sample when the coprolite was very small, fragmented, or had a very friable consistency. In these cases, the entire subsample (interior and exterior) was processed for this analysis. Coprolite subsamples were soaked for $24-96 \mathrm{~h}$ in a $0.5 \%$ sodium phosphate solution until rehydrated and softened (Callen and Cameron 1960). The color of the solution (using a Munsell color chart) and opacity was recorded after the coprolites were rehydrated (Bryant 1974b). The coprolite samples are summarized in Table 1.

\section{Radiocarbon dating}

Macrofossils were recovered from coprolites 55, 98, and 242 following the methods described below, then dried,
Fig. 3 Summary of coprolite sampling methodology

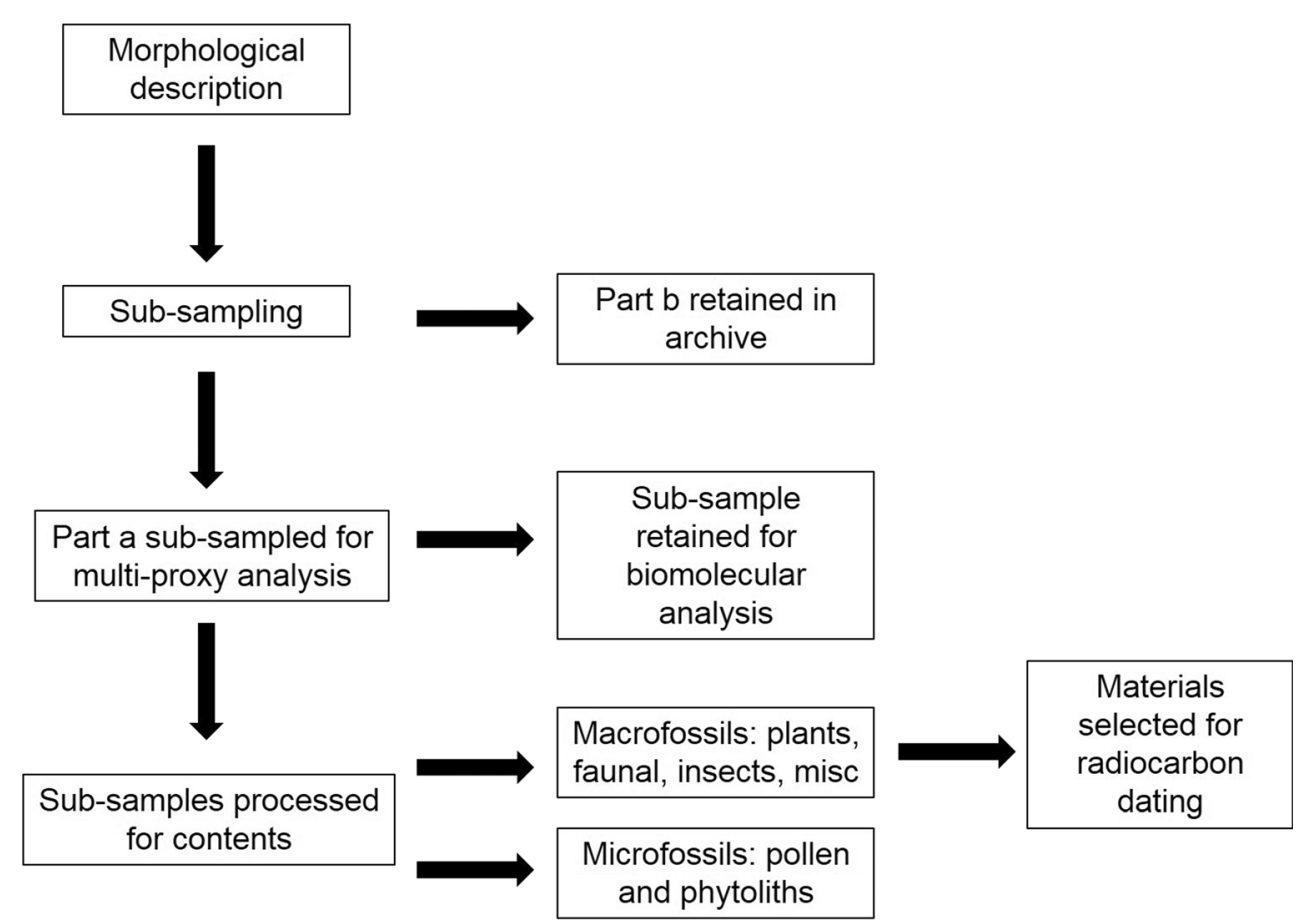




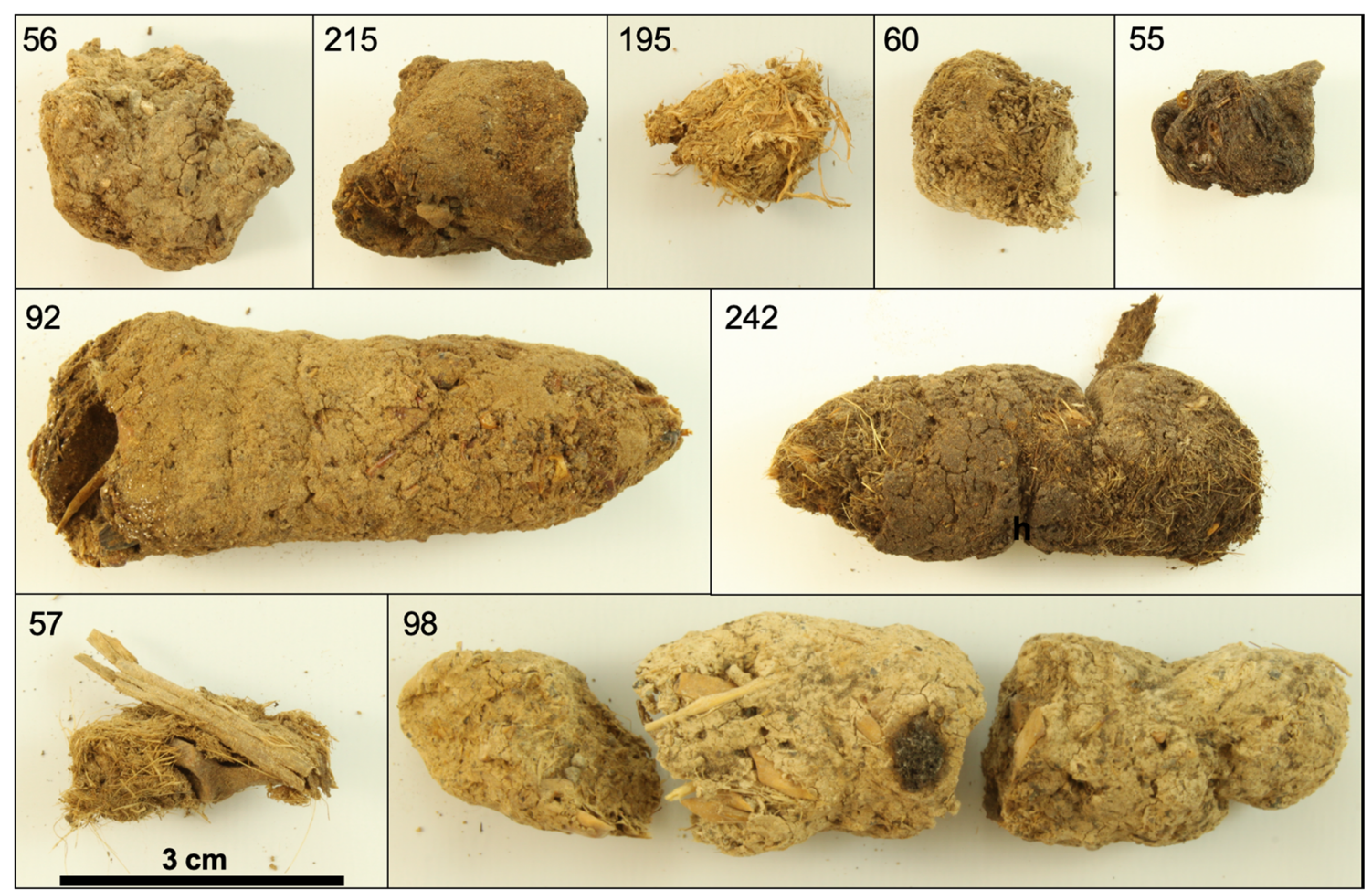

Fig. 4 Images of the nine Paisley Caves coprolites prior to collecting the subsamples processed for this study. Sample information in Table 1

weighed, and submitted for radiocarbon analysis. Samples consisted of combined plant material (e.g., plant fiber, charcoal fragments); this was deemed appropriate because coprolites represent a tightly constrained context and there is little chance for intrusive macroscopic organic material that might contaminate radiocarbon samples. Samples were sent to the Oxford Radiocarbon Accelerator Unit for AMS analysis.

\section{Analysis of contents}

Between two and four Lycopodium clavatum marker spore tablets (batch number 3862; 9666 spores per tablet) were added to each rehydrated coprolite sample to enable pollen concentration calculation (Bryant Jr and Hall 1993; Davis 1966; Stockmarr 1971). The rehydrated coprolite material was gently disaggregated, screened through $250-\mu \mathrm{m}$ mesh sieve, then finished with a spray of ethanol to break surface tension and release any microfossils trapped in the screen. The $>250-\mu \mathrm{m}$ material remaining on the screen was stored in distilled water at $4{ }^{\circ} \mathrm{C}$ for macrofossil analysis. The $<250-\mu \mathrm{m}$ material was treated with a $5 \%$ solution of sodium hexametaphosphate to disaggregate the sample and remove any clay particles. The liquefied < $250-\mu \mathrm{m}$ material was then split evenly into phytolith and pollen subsamples.

\section{Plant and animal macrofossil analysis}

Macrofossil remains were suspended in a glass dish containing distilled water and examined with the aid of a stereomicroscope under $\times 20$ to $\times 40$ magnification to separate different coprolite components (e.g., stone, insect, plant fiber, seeds). The resulting groups of material were dried in an oven at $100{ }^{\circ} \mathrm{C}$, then weighed. Raw weight data is presented as well as percent weight calculated by dividing the weight of individual components by the total weight of all $<$ $250-\mu \mathrm{m}$ macrofossil material. Percent weight of material per sample is used to make the data more comparable between coprolites (Faulkner 1991; Fry 1970). Seeds, bone, and insect remains were counted and are presented as the total number of fragments (NISP) and estimated minimum number of individual (MNI) specimens (Grayson 1984). For seeds, the MNI estimate is based on the number of fragments representing more than $50 \%$ of a seed as well as the presence/absence of distinctive features (e.g., hilum). Plant macrofossil analysis primarily focused on seeds as these can often be identified with high taxonomic resolution (Birks 2007). Seed identifications were made using reference material at Newcastle University as well as seed reference material obtained from the USDA National Clonal Germplasm Repository (https://npgsweb.ars-grin.gov/gringlobal/ search.aspx) and online resources specific to the Great Basin (https://nhmu.utah.edu/native-plants). 


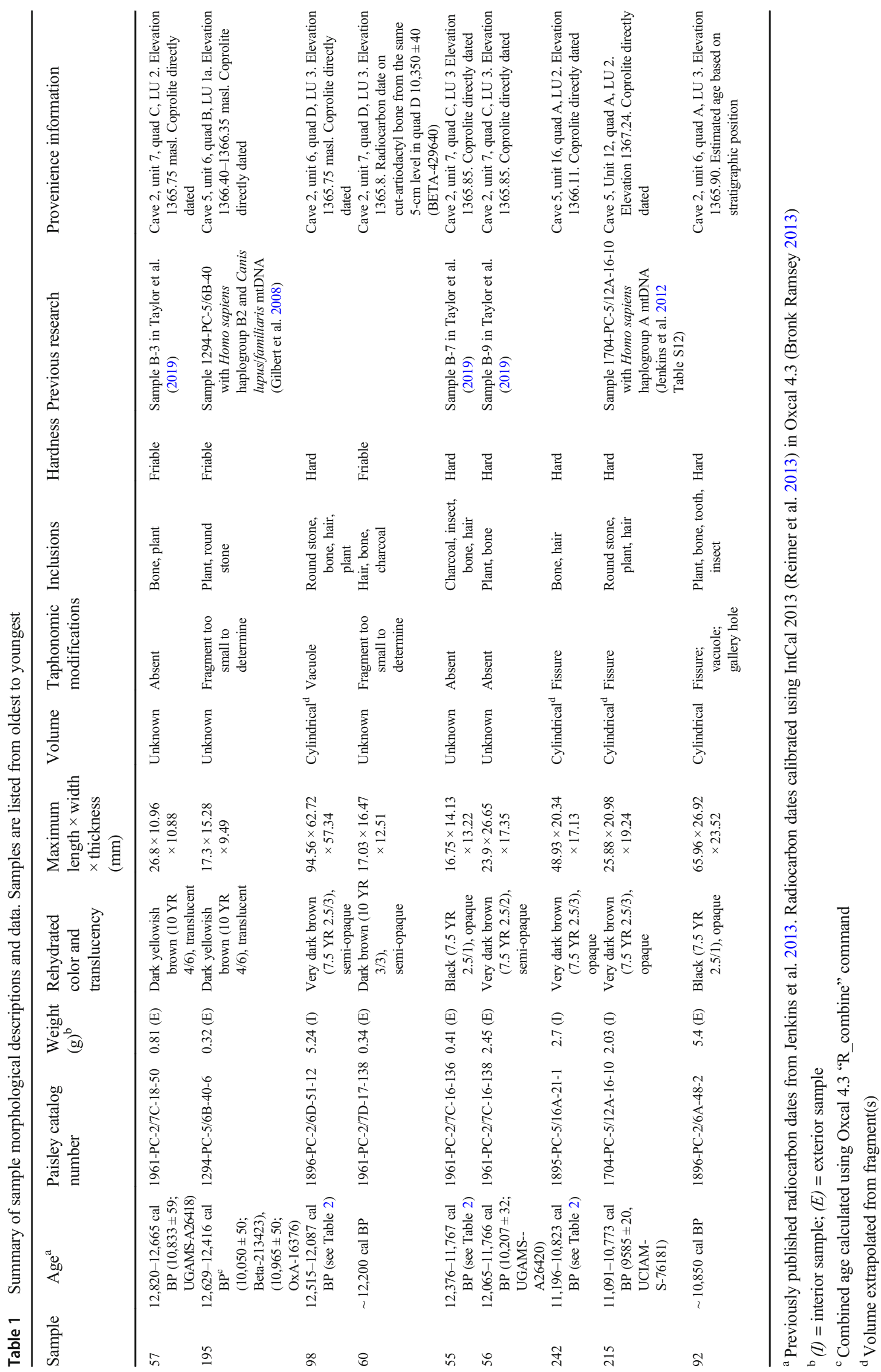


The faunal analysis focused on both cranial and postcranial elements. Lab protocols and faunal identifications were conservative (Driver 2011; Gobalet 2001). Fauna identifications were completed under magnification (i.e., $\times 10, \times 20$, and $\times$ $40)$ with the aid of a stereomicroscope. Bird and mammal remains were identified using osteological comparatives housed at the Museum of Vertebrate Zoology, University of California, Berkeley. Fish remains were identified using an osteological collection housed in the Department of Anthropology, University of California, Berkeley and supplemented by specimens from the California Academy of Sciences Ichthyology Collection, San Francisco, California. This study follows the standard of Page et al. (2013) for scientific and common names of fishes. Osteological and NISP data were recorded for each skeletal specimen (Grayson 1984; Lyman 2008). Unidentified fragments $<0.25 \mathrm{~mm}$ are not included in the NISP counts. Taphonomic analysis of faunal remains follows the protocols outlined by Fisher Jr (1995) and Butler and Schroeder (1998).

Insect remains were examined under a dissecting microscope and identified to the highest resolution taxonomic classification possible using classification keys and other references (Bousquet et al. 2018; Doyen 1984; Fisher and Cover 2007; Hebard 1916; Young 1988), as well as online resources, including the Global Biodiversity Information Facility (https://www.gbif.org) and Harvard's Museum of Comparative Zoology (https://mcz.harvard.edu). Nomenclature follows Bousquet et al. (2018), Doyen (1984), and Fisher and Cover (2007). Voucher specimens are curated at the Oregon Museum of Natural and Cultural History archaeological research laboratory at the University of Oregon, Eugene.

\section{Pollen analysis}

The pollen subsample was acetolyzed (Erdtman 1960; Hesse and Waha 1989) to remove nonsporopollenin organic compounds, separated using sodium polytungstate calibrated to a density of $1.9 \mathrm{~g} / \mathrm{cm}^{3}$, stained with safranin, then stored in glycerol. A small amount of pollen sample was mounted with glycerol on a glass slide and analyzed using a light microscope at $\times 200$ and $\times 400$ magnification. Pollen analysis consisted of a minimum of 200 indigenous terrestrial and aquatic grain count, except for samples with poor pollen preservation (see below). A 200-grain count is standard protocol for coprolite studies and is adequate for samples with low taxonomic diversity (Faegri and Iversen 1989; Moore et al. 1991). Pollen recovered from the coprolites was compared to reference material at Newcastle University and the Garrett Herbarium at the Utah Museum of Natural History, published reference literature (Faegri and Iversen 1989; Kapp et al. 2000; Moore et al. 1991), and online pollen image databases (e.g., https:// globalpollenproject.org; http://www.paldat.org). Pollen in the family Asteraceae was identified as either Artemisia type, low-spine, high-spine, or dandelion type following Martin (1963).

Aggregate pollen grains were counted as a single grain so that their frequency did not overwhelm the other taxa present in the sample (Sobolik 1988). The procedure was also necessary because it was not possible to get an accurate count of the number of grains in densely packed pollen aggregates. Pollen counts were converted to pollen frequency (percentage of the sum for each sample) to enable comparison between samples with variable total pollen counts (Faegri and Iversen 1989; Moore et al. 1991). Pollen concentration value per gram of coprolite sample was calculated using the formula below (following Benninghoff 1962 and Maher 1981). Approximate pollen concentrations for each taxon were calculated by multiplying total concentration value by relative frequency for each pollen taxon (Dean 1993). Pollen data is diagrammed using C2 stratigraphic software (Juggins 2007).

Total indigenous pollen counted $\times \#$ L.clavatum added

\section{Weight in grams of sample $\times \#$ L.clavatum counted}

Pollen can enter the human digestive system through multiple pathways - ambient pollen is in the air we breathe, the water we drink, and the food we eat (Bryant 1974b; Bryant and Holloway 1983; Martin and Sharrock 1964). Therefore, not all pollen recovered from fecal matter is linked to dietary choices. To address these potential biases, our analysis followed established criteria for linking pollen data with intentional dietary or medicinal consumption of plant material (Bryant 1974a, 1974b; Reinhard et al. 1991; Sobolik 1988).

Pollen aggregates for both anemophilous (wind-pollinated) and entomophilous (insect-pollinated) taxa often indicate intentional consumption of that taxa. Larger aggregates of a single pollen type typically represent consumption of pollen from the anther of a flower; smaller aggregates can indicate consumption of foliage and seeds of that taxon (Bryant 1974a).

Pollen produced by an entomophilous taxon and present in frequencies $\geq 4 \%$ (the typical upper frequency of entomophilous taxa in ambient pollen rain) and/or in concentration above the mean for that taxon across all samples provides evidence for intentional consumption of the flowers, buds, foliage, or seeds of that taxon (Dean 1993; Reinhard et al. 1991; Reinhard 1993; Sobolik 1988). Anemophilous taxa produce pollen in relatively high frequencies and are commonly incorporated into ambient pollen rain; therefore, linking frequencies of pollen from anemophilous taxa to intentional consumption is somewhat more problematic (Bryant and Holloway 1983; Martin and Sharrock 1964; Reinhard et al. 1991). However, ambient pollen should be represented in relatively equal amounts across a series of coprolites from the same site (Dean 1993; Reinhard et al. 1991). This study 
compares the relative frequency and concentration of anemophilous taxa to the mean of that taxa across the entire series of coprolites as well as naturally derived paleoenvironmental samples from the study area to identify intentional consumption. High relative frequencies ( $>40 \%)$ and concentrations $(<$ 100,000 grains per gram of coprolite) of pollen from anemophilous taxa are considered to represent intentional consumption because frequencies and concentrations higher than this are not typically observed in naturally derived samples (Bryant 1974a; Reinhard et al. 1991).

\section{Phytolith analysis}

The phytolith subsample liquid was placed in a crucible and dried at $150{ }^{\circ} \mathrm{C}$, then placed in a muffle furnace for $2 \mathrm{~h}$ at $500{ }^{\circ} \mathrm{C}$ to remove organic matter. Phytolith material was separated using sodium polytungstate calibrated to a density of $2.3 \mathrm{~g} / \mathrm{cm}^{3}$, then dried. A known weight of the resulting material was permanently mounted in Entellan mounting agent on a $22 \times 22-\mathrm{mm}$ slide. Phytoliths were analyzed with a light microscope at $\times 200$ and $\times 400$ magnification. Density of phytoliths per gram of coprolite was calculated by studying a known number of fields at $\times 400$ magnification. At this magnification, there are 48 fields of view in one $22-\mathrm{mm}$ column of the slide, which equals 2304 total fields of view on the slide. Density per gram was calculated employing the formula below and is used to compare relative inputs of plant material into the diet.

Phytoliths per slide $=\left(\frac{\text { phytolith count }}{\text { fields counted }}\right) \times$ total fields on slide

$\left(\frac{\text { phytoliths per slide }}{\text { phytoliths mounted }(\mathrm{mg})} \times \frac{\text { mass phytoliths extracted }(\mathrm{mg})}{\text { coprolite weight }(\mathrm{mg})}\right) \times 1000$

Phytoliths were grouped into morphotypes based on threedimensional shape. Phytolith counts consisted of between 200 and 300 single-cell and between 50 and 100 multicell phytoliths. If 300 single cells were counted before 50 multicell phytoliths were observed, then counting for that sample stopped. Previous studies have shown that counting 265 phytoliths with consistent morphology gives a $12 \%$ error margin (Albert and Weiner 2001). Phytolith counts were converted to relative frequency by dividing the count of morphological types by the total phytolith count for that sample enabling comparison between coprolites. Single-cell and conjoined phytolith counts are presented separately.

Monocotyledon plants (monocots) are dominated by members of the Orchidaceae (orchid) and Poaceae (grass) families. Most monocots produce abundant phytoliths, and particular species of grasses typically produce high frequencies of specific morphotypes (Blinnikov 2005; Twiss et al. 1969). Short-cell phytoliths are formed in specialized grass epidermis cells and lie across the veins of the leaf and leaf-derived tissues (e.g., glumes, husks) and sometimes in cells lying between the veins (Pearsall 2015, p. 256). Short cells are abundantly produced by grasses and may be very common in archaeological samples. Long-cell phytoliths are formed in nonspecialized grass epidermal cells. Length, wall thickness, and surface ornamentation of long cells are diverse, and they often have limited usefulness for distinguishing among grass species (Pearsall 2015, p. 256; Twiss et al. 1969). Trichome phytoliths and silicified hairs and bases typically form in epidermal appendages on grass blades (Blinnikov 2005). Dendritic long cells and scutiform/papillae phytoliths are formed in grass seed epidermal cells; these types are produced during the months tied to plant flowering and fruiting times and are therefore useful for assessing season of consumption (Harvey and Fuller 2005, p. 743).

Dicotyledon (dicots) plants are dominated by herbaceous forbs. Dicots generally produce lower frequencies of phytoliths than monocots (Piperno 1988). Studies of Great Basin taxa indicate this holds true for dicots from the study region (Morris et al. 2009). Epidermal polygonal phytoliths are typical of dicots but are also largely nondiagnostic from one taxon to the next (Pearsall 2015). Dicot samples collected in the Great Basin commonly produced hairs, anticlinal and polyhedral epidermal sheets, and tracheids (Morris et al. 2009).

Relative counts of the morphotypes described above are used to distinguish the consumption of monocot (e.g., grasses) and dicot (e.g., forbs) plant material and, when possible, to identify consumed plant parts within these broader plant groups. The morphotypes in this study follow those established for plant taxa common to the Pinyon-juniper woodlands and sagebrush grassland steppe of the Great Basin (Morris et al. 2009) and interior Pacific Northwest (Blinnikov 2005).

\section{Results}

\section{Radiocarbon dating}

This study presents new radiocarbon dates on three previously undated coprolites: two yielding calibrated radiocarbon ages in the YD period and one in the EH (Table 2). When combined with previously published dates and estimated ages based on stratigraphic provenience, the nine coprolites presented here broadly cluster into YD-aged occupations $(12,800-11,700$ cal BP) represented by six samples and EHaged occupations $(11,200-10,850 \mathrm{cal} \mathrm{BP})$ represented by three samples (Fig. 5). 
Table 2 New radiocarbon dates on Paisley Caves coprolites. Radiocarbon dates calibrated using IntCal 2013 (Reimer et al. 2013) in Oxcal 4.3 (Bronk Ramsey 2013)

\begin{tabular}{llllll}
\hline Coprolite sample & Material & $\delta^{13} \mathrm{C}(\% \circ)$ & ${ }^{14} \mathrm{C}$ BP & Cal BP $(2 \sigma)$ & Laboratory number \\
\hline 98 & Bulk sample: uncharred, unidentified plant fiber & -22.43 & $10,407 \pm 37$ & $12,515-12,087$ & OxA-38445 \\
55 & Bulk sample: charcoal and uncharred, unidentified plant fiber & -25.91 & $10,262 \pm 57$ & $12,376-11,767$ & OxA-38674 \\
242 & Bulk sample: charcoal and uncharred, unidentified plant fiber & -23.43 & $9663 \pm 29$ & $11,196-10,823$ & OxA-38415 \\
\hline
\end{tabular}

\section{Plant and faunal macrofossil analysis}

Table 3 provides a summary of results for all coprolites analyzed for this study. A variety of plant, animal, and stone material was recovered from each of the nine coprolites (Table 4). Plant fiber was present in all samples, consisting of anywhere from 0.3 to $69.15 \%$ of the total macrofossil weight. Sand to pebble-sized angular to round stone was present in all samples, including interior samples not in contact with the surrounding matrix. The diversity of plant remains across the nine coprolites is notable; there are very few identified taxa that repeat from one coprolite to another. Seed was present in six coprolites, although in low frequencies (Fig. 6). Coprolite 56 contained Rosa cf. woodsii (Wood's rose) seed and possible fruit skins likely representing consumption of rose hips (Fig. 7a). Coprolites 57 and 242 contained Typha sp. (cattail) seed (Fig. 7e), coprolite 242 contained Carex sp. (sedge) seed (Fig. 7g), coprolite 98 contained cf. Amaranthaceae (amaranth family) seed (Fig. 7d), coprolite 215 contained cf. Amaranthus sp. (amaranth) (Fig. 7f) and cf. Descurainia pinnata (tansy mustard) seed (Fig. 7b), coprolite 92 contained cf. Poaceae (grass family) caryopses that appear to have been significantly impacted by food processing and/or digestion (Fig. 7c), and coprolites 92 and 98 contained unidentified seed types. None of the seeds appear to be carbonized.

Faunal material was recovered in each of the nine coprolites (Table 5, Fig. 8). Most of the faunal material was highly fragmented with evidence of digestive processes, especially acid-etching and rounding, and could only be identified to broad categories. Identified taxa include Lepus sp. (hare/jackrabbit) (Fig. 9a), Rodentia (Fig. 9b-d), Catostomidae/Cyprinidae (fish), and Aves (bird). Rodentia bones are linked with a significant amount of animal hair in coprolite 56.

Eight of the Paisley coprolites contained insect remains (Table 6, Fig. 10), many of which could not be securely identified because they were too damaged from processing and/or digestion. The majority of insect remains were recovered from coprolite 92 and include remains from Polyphylla cf. decemlineata (ten-lined June beetle) (Fig. 11a), Stenopelmatus cf. fuscus (Jerusalem cricket), and the remains of individuals in the family Tenebrionidae (darkling beetles), including Eleodes obscura sulcipennis (Fig. 11b) and Eusattus muricatus (Fig. 11c). Coprolite 92 contained many unidentified

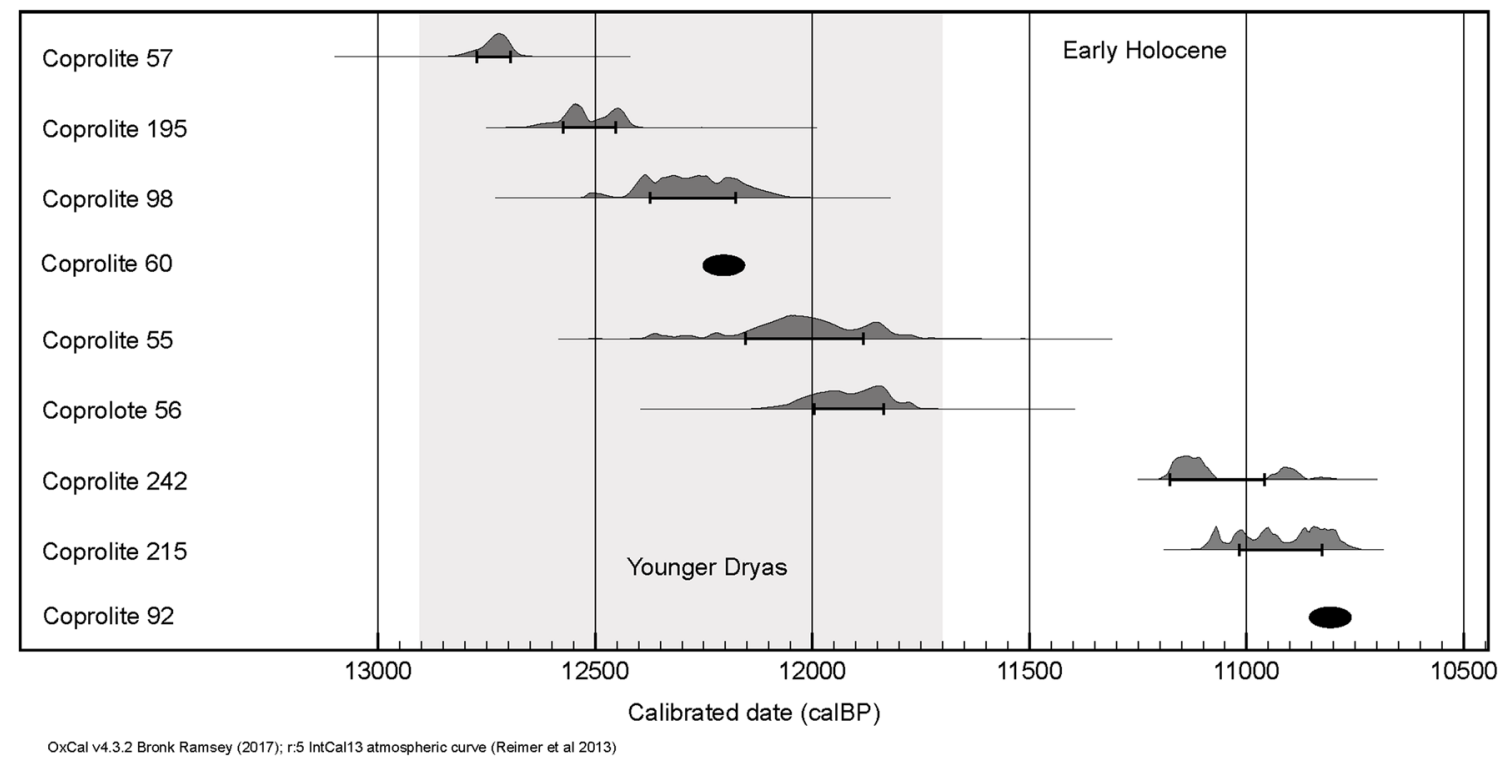

Fig. 5 Age of the nine coprolites presented in this study: gray distribution curves represent calibrated radiocarbon age; black ovals represent estimated age based on stratigraphic position. Coprolite 195 combined age calculated using Oxcal 4.3 "R_combine" command (Bronk Ramsey 2013) 


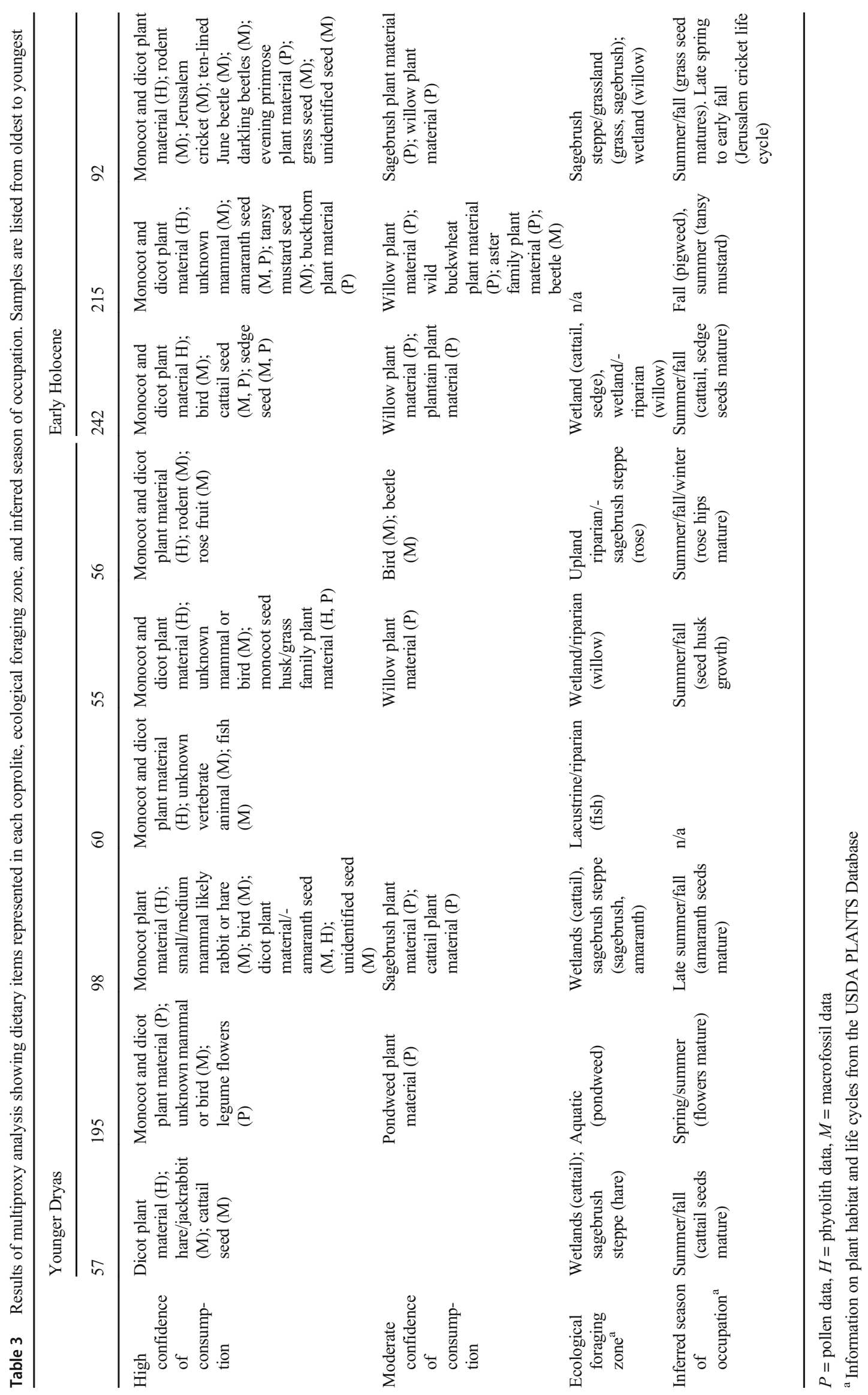




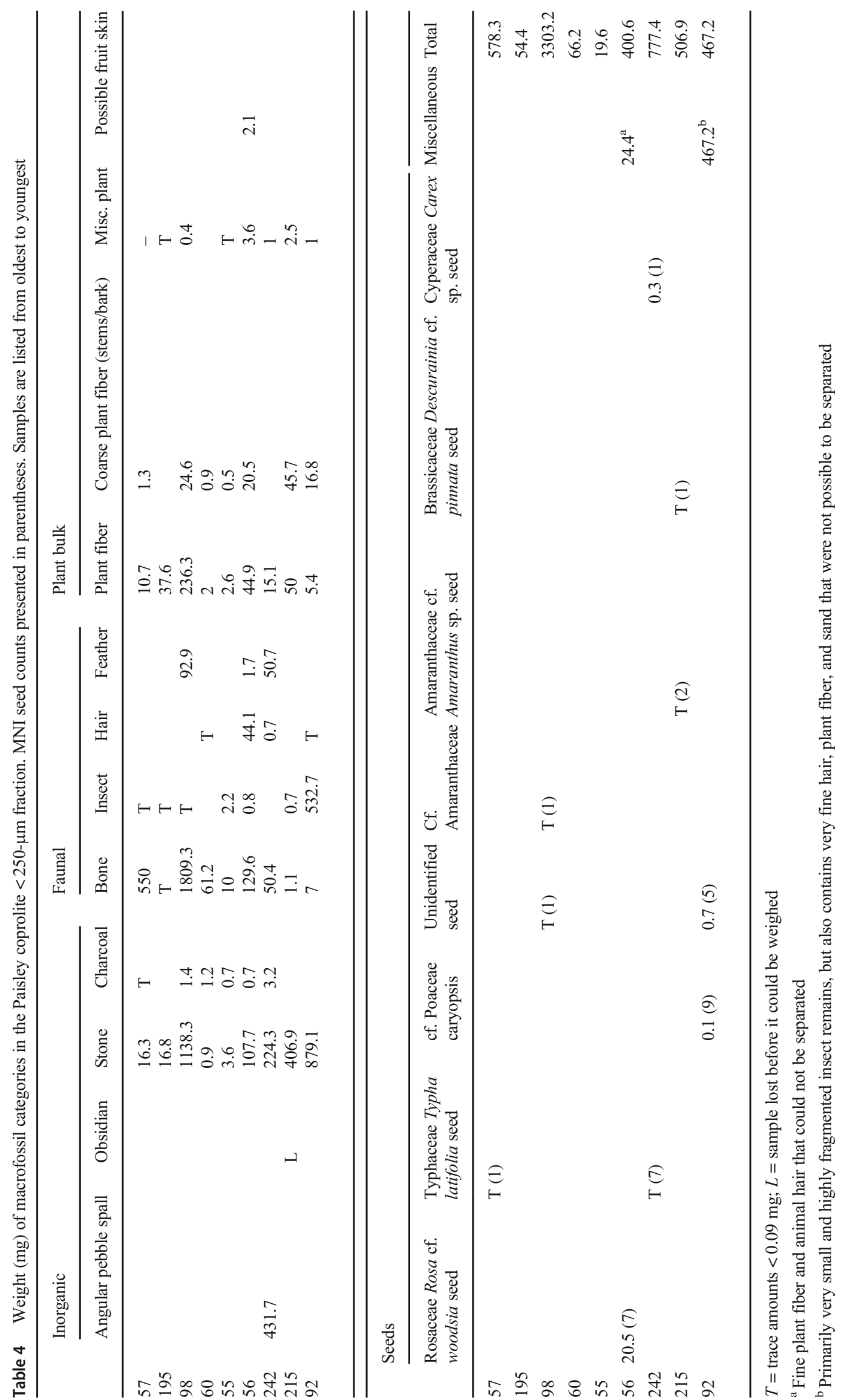


Fig. 6 Bar chart showing total seed MNI in each coprolite

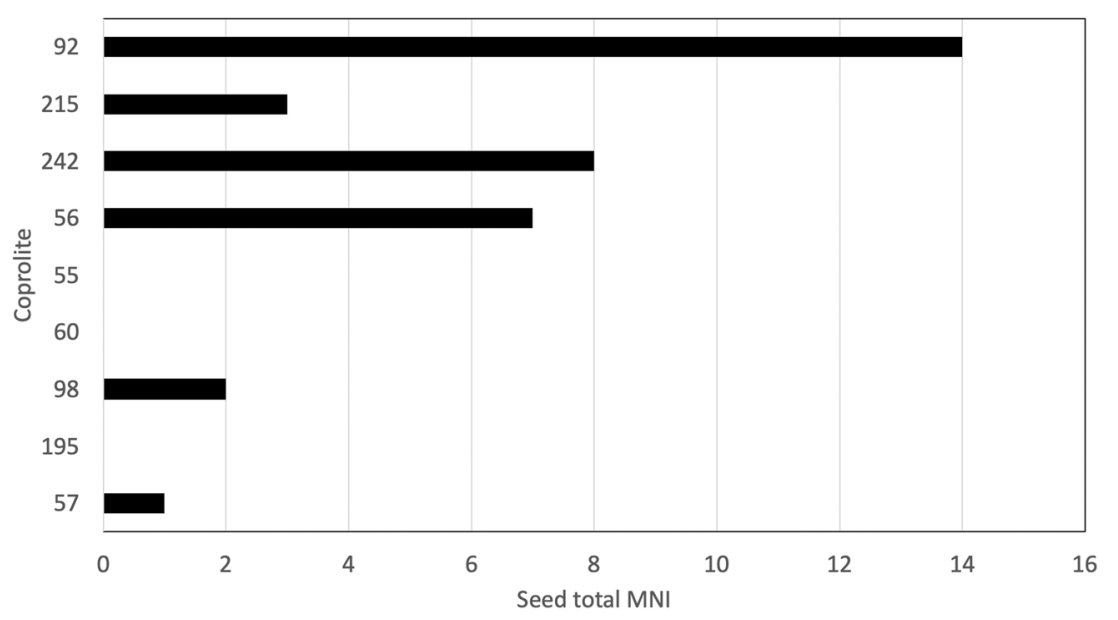

remains of tenebrionids that are likely additional fragments of Eusattus or Eleodes. Coprolites 56 and 215 contained remains of individuals from the order Coleoptera.

Coprolites 56 and 195 contained remains of very small ants, likely from the genus Camponotus (carpenter ants). Coprolites 55 and 57 contained larval fly (maggot) puparium fragments. 470 insect elements or fragmentsprimarily from coprolite 92 - were classified as indeterminate order; most of these elements are likely linked to the taxa described above.

\section{Pollen}

Coprolites 55, 56, 57, 60, 92, and 195 were processed with both interior and exterior coprolite material, so the pollen counts for these coprolites may contain pollen from the surrounding soil matrix in addition to pollen from the digestive system of the individual. However, this should only introduce pollen types already present in the ambient pollen rain, and the introduced grains should not exceed ambient levels for these taxa. Coprolite pollen data are compared to previously published pollen frequencies in YD- and EH-aged sediment

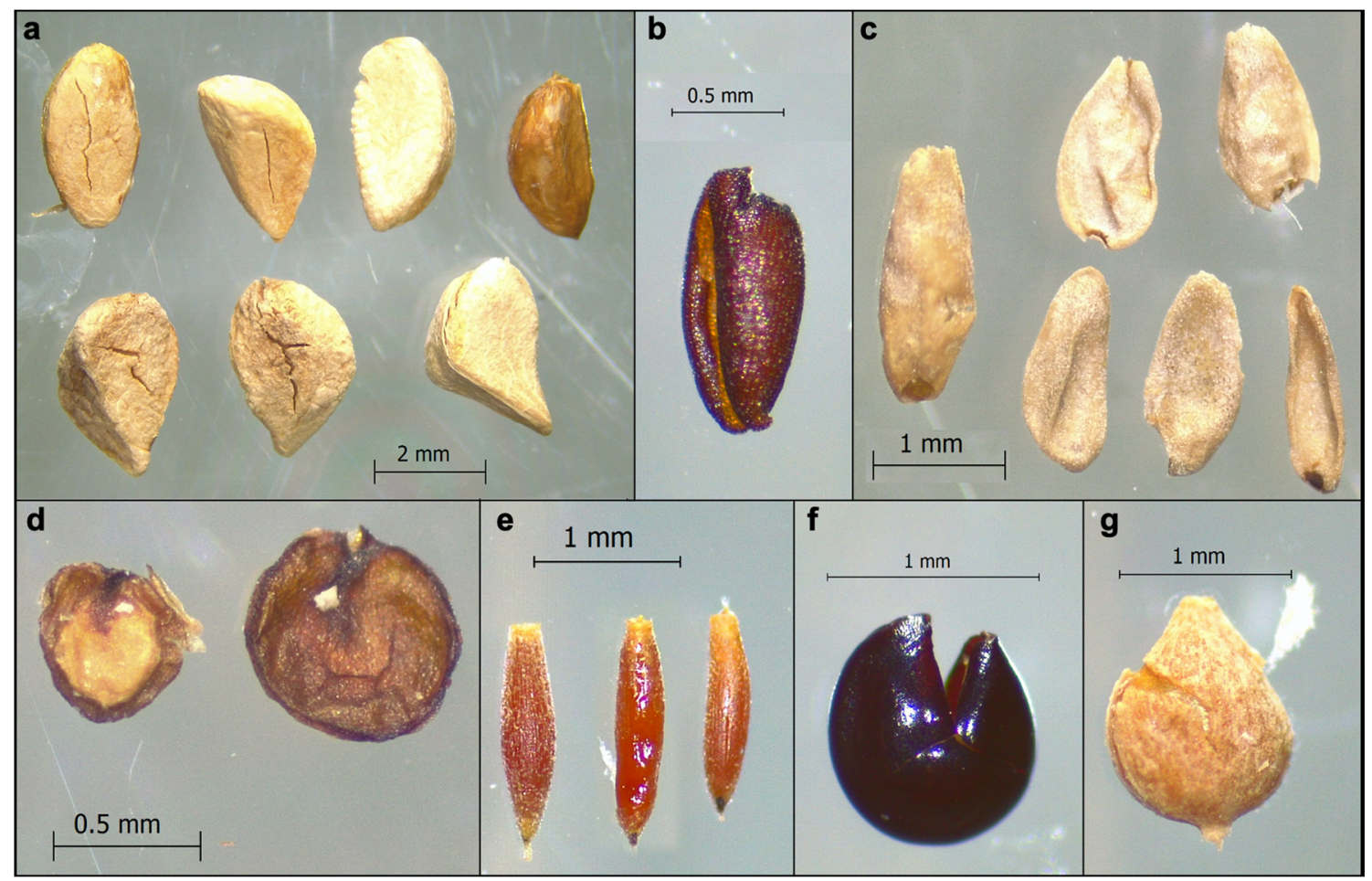

Fig. 7 Plant macrofossils identified from the Paisley Caves coprolites: a coprolite 56 Rosa cf. woodsii seeds, b coprolite 215 cf. Descurainia pinnata seed, c coprolite $92 \mathrm{cf}$. Poaceae caryopsis, d coprolite $98 \mathrm{cf}$. Amaranthaceae seeds, e coprolite 242 Typha sp. seeds, f coprolite 215

cf. Amaranthus sp. seed, g coprolite 242 Carex sp. seed. Complete macrofossil data is presented in the supplementary material (Online Resource 1) 
Table 5 Summary table of faunal remains recovered from Paisley coprolites

\begin{tabular}{|c|c|c|c|c|c|c|c|c|c|c|}
\hline Taxon & $\begin{array}{l}57 \\
\text { NISP }\end{array}$ & $\begin{array}{l}195 \\
\text { NISP }\end{array}$ & $\begin{array}{l}98 \\
\text { NISP }\end{array}$ & $\begin{array}{l}60 \\
\text { NISP }\end{array}$ & $\begin{array}{l}55 \\
\text { NISP }\end{array}$ & $\begin{array}{l}56 \\
\text { NISP }\end{array}$ & $\begin{array}{l}242 \\
\text { NISP }\end{array}$ & $\begin{array}{l}215 \\
\text { NISP }\end{array}$ & $\begin{array}{l}92 \\
\text { NISP }\end{array}$ & $\begin{array}{l}\text { Total } \\
\text { NISP }\end{array}$ \\
\hline Vertebrata & & 2 & & 87 & & & & & & 89 \\
\hline Mammalia/Aves & 36 & & 244 & & 3 & 230 & & & & 513 \\
\hline Mammalia & & & & & & & & 43 & & 43 \\
\hline Lepus (hare/jackrabbit) & 1 & & & & & & & & & 1 \\
\hline Small/medium mammal & & & 4 & & & & & & & 4 \\
\hline Very small/small mammal & & & & & & & & & 62 & 62 \\
\hline Rodentia & & & & & & 15 & & & 4 & 19 \\
\hline \multicolumn{11}{|l|}{ Actinopterygii } \\
\hline Catostomidae/cyprinidae (fish) very small & & & & 1 & & & & & & 1 \\
\hline Aves & & & & & & & 35 & & & \\
\hline Total & 37 & 2 & 248 & 88 & 3 & 245 & 35 & 43 & 66 & 767 \\
\hline
\end{tabular}

samples collected in the Paisley Caves as well as modern surface samples collected in a $50-\mathrm{km}^{2}$ region surrounding the Paisley Caves (Beck et al. 2018). These data establish a baseline expectation for ambient pollen rain frequencies.

All nine of the Paisley coprolites contained pollen (Fig. 12), but coprolites 57 and 60 did not contain autochthonous pollen in any meaningful amount and are not discussed further. Pollen count, frequency, concentration, and aggregate data are presented in the supplementary material (Online Resource 1). Total pollen concentration in the remaining seven samples was variable, ranging from 29,373 to 288,075 grains per gram of coprolite material, well above the 1000 grains per gram concentration suggested for reliable results in sediment samples (Bryant and Hall 1993). The following results highlight patterns in the pollen data that fit the criteria for intentional consumption established above.

Coprolite 195 contained $8 \%$ of a single type of entomophilous Fabaceae (legume) pollen (Fig. 13a), including eight aggregates estimated to contain more than 1130 grains (Fig. 13b). Potamogeton sp. (pondweed) pollen is anemophilous and present in relatively low frequency (3\%), but this taxon is not represented in any coprolites in this study or in previously published coprolite and sediment samples from the Paisley Caves (Beck et al. 2018; Cummings et al. 2007; Taylor et al. 2019).

Coprolite 98 contained a single aggregate of approximately 30 anemophilous Typha latifolia (cattail) pollen grains (Fig. 13c) and contained 15\% Typha pollen when the aggregate count is included, well above the mean for all coprolites and the frequency in sediment samples collected in and outside of Paisley Caves. Coprolite 98 also contained a single aggregate of Artemisia pollen containing approximately six grains, and the frequency of Artemisia pollen (43\%) is more than double the mean of Artemisia across all coprolites. Artemisia can be entomophilous but is more commonly anemophilous. Coprolite 55 contained $13 \%$ anemophilous Poaceae pollen in a concentration of 4394 grains per gramabove the mean for the entire coprolite series. Poaceae pollen is not present in amounts exceeding $5 \%$ in sediment samples from the caves but comprises up to $30 \%$ of the pollen rain outside of the caves. Salix sp. (willow) pollen represents $4 \%$ of the total pollen in coprolite 55. Salix is typically
Fig. 8 Bar chart showing total bone NISP in each coprolite

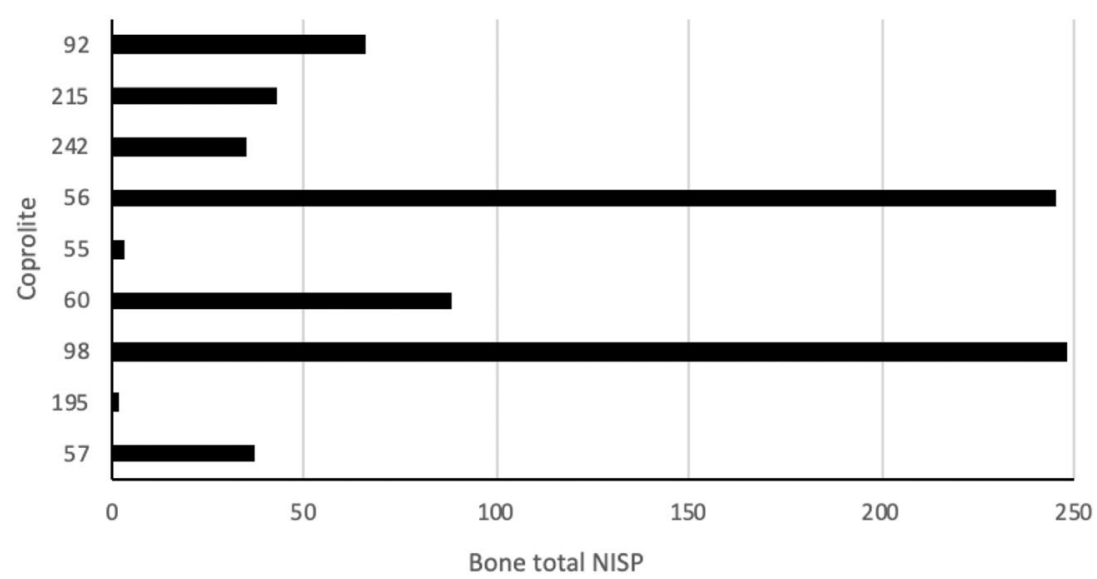


Fig. 9 Faunal material identified in the Paisley Caves coprolites: a Coprolite 57 Lepus sp. calcaneus (left is the coprolite specimen and right is the reference specimennote acid modification on coprolite specimen). b Coprolite 92 Rodentia vertebra fragment. c Coprolite 56 Rodentia corpus unguis. d Coprolite 56 Rodentia phalanges

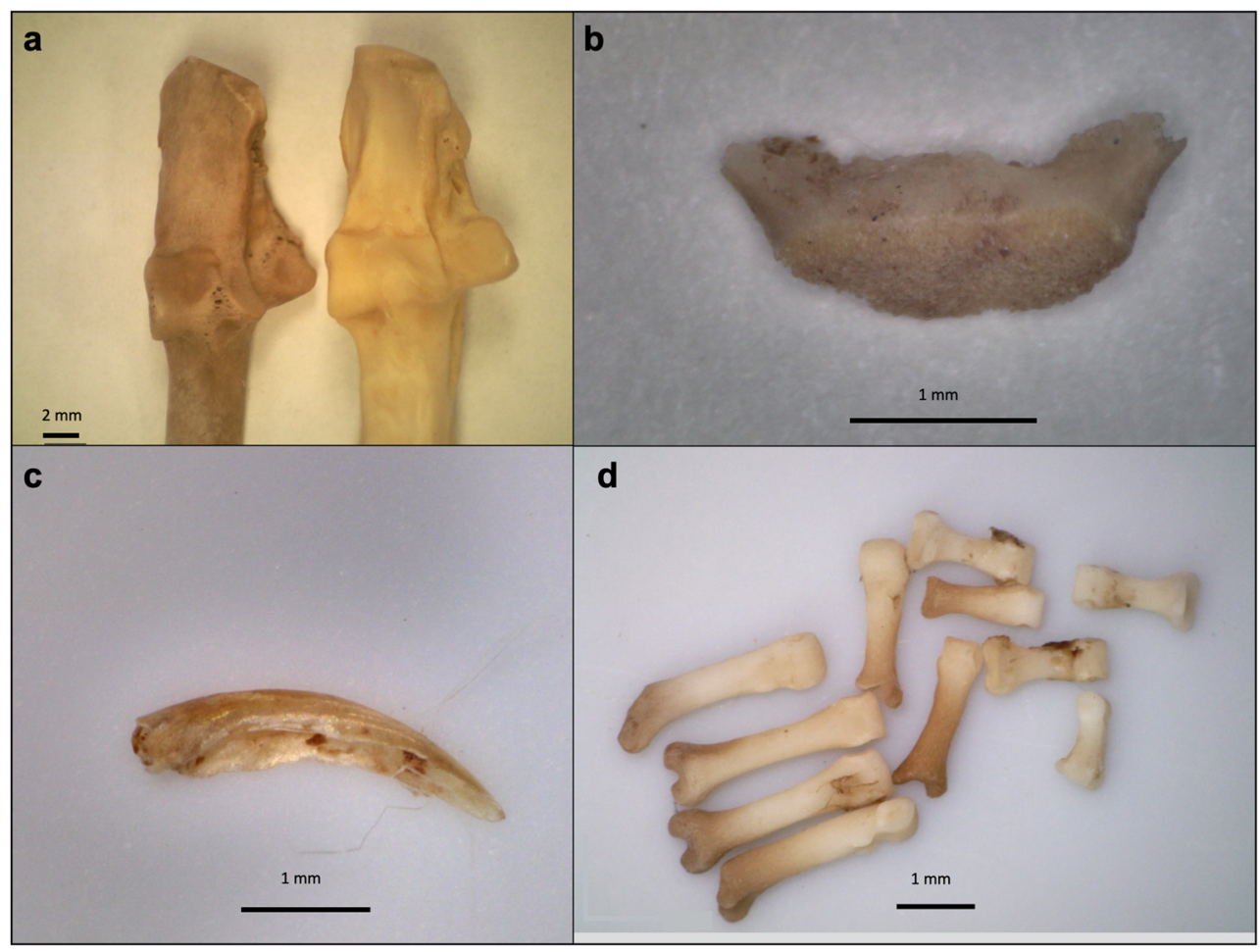

entomophilous pollinated (Reinhard et al. 1991), and Salix is present in amounts less than $1 \%$ in sediments collected in and outside of the caves. However, the mean frequency for Salix pollen across all coprolites is $4 \%$, suggesting that this may represent ambient levels of this pollen type.

Coprolite 242 contained high frequency and concentration of anemophilous Cyperaceae (sedge) and Typha latifolia pollen compared to the mean for all coprolites and sediment samples collected in and outside of the caves. Salix pollen is present in a frequency well above the mean (14\%) including an aggregate of $\sim 10$ grains. Coprolite 242 also contained $9 \%$ Plantago sp. (plantain) pollen (Fig. 13d); this genus is typically anemophilous (Faegri and Iversen 1989; Sharma et al. 1993), but it is not present in other coprolites in this study or in sediment samples.

Coprolite 215 contained high frequency and concentration of anemophilous Amaranthaceae pollen compared to the mean for all coprolites, including a single aggregate of four grains, and a high concentration of anemophilous low-spine Asteraceae pollen grains, including a large aggregate of $\sim 32$ grains (Fig. 13e). Coprolite 215 also contained a high frequency $(13 \%)$ of single type of entomophilous Rhamnaceae (buckthorn family) pollen (Fig. 13f), entomophilous Eriogonum (buckwheat) pollen in a frequency and concentration above the mean for all coprolites and sediment samples, and Salix in high concentration relative to the mean for all coprolites. Coprolite 92 contained a high frequency of entomophilous Onagraceae cf. Chamerion type pollen (Fig. 13g) and Salix pollen, as well as a high frequency of Artemisia pollen compared to sediment samples, including an aggregate comprised of six grains.

\section{Phytoliths}

Phytoliths in the Paisley Caves coprolites are well-silicified, indicating the region was favorable for phytolith development and preservation. Most of the coprolites contained phytolith morphotypes representing both monocot and dicot plant types, in particular epidermis (leaf) material from these two plant types (Fig. 14, Online Resource 1). Phytolith density was variable between samples, ranging from an estimated 119 to 476,370 phytoliths per gram of coprolite (Fig. 15). The phytolith samples from coprolites $55,56,60,92$, and 215 primarily consist of morphotypes representing monocot epidermal material (Fig. 16), including conjoined phytoliths representing monocot epidermal sheets (Fig. 17a, b). These five samples also contained phytolith morphotypes representing dicot epidermal material but in lesser amounts (Fig. 17c). Coprolite 55 contained a high frequency of monocot morphotypes and a small number of single and conjoined dendritic phytoliths representing grass seed husks (Fig. 17d). The phytolith samples from coprolites 98 and 195 are more evenly split between phytoliths representing monocot and dicot epidermal material (Fig. 17e-g). The phytolith sample from coprolites 57 and 242 primarily consists of morphotypes representing dicot epidermal material (Fig. 17g). 


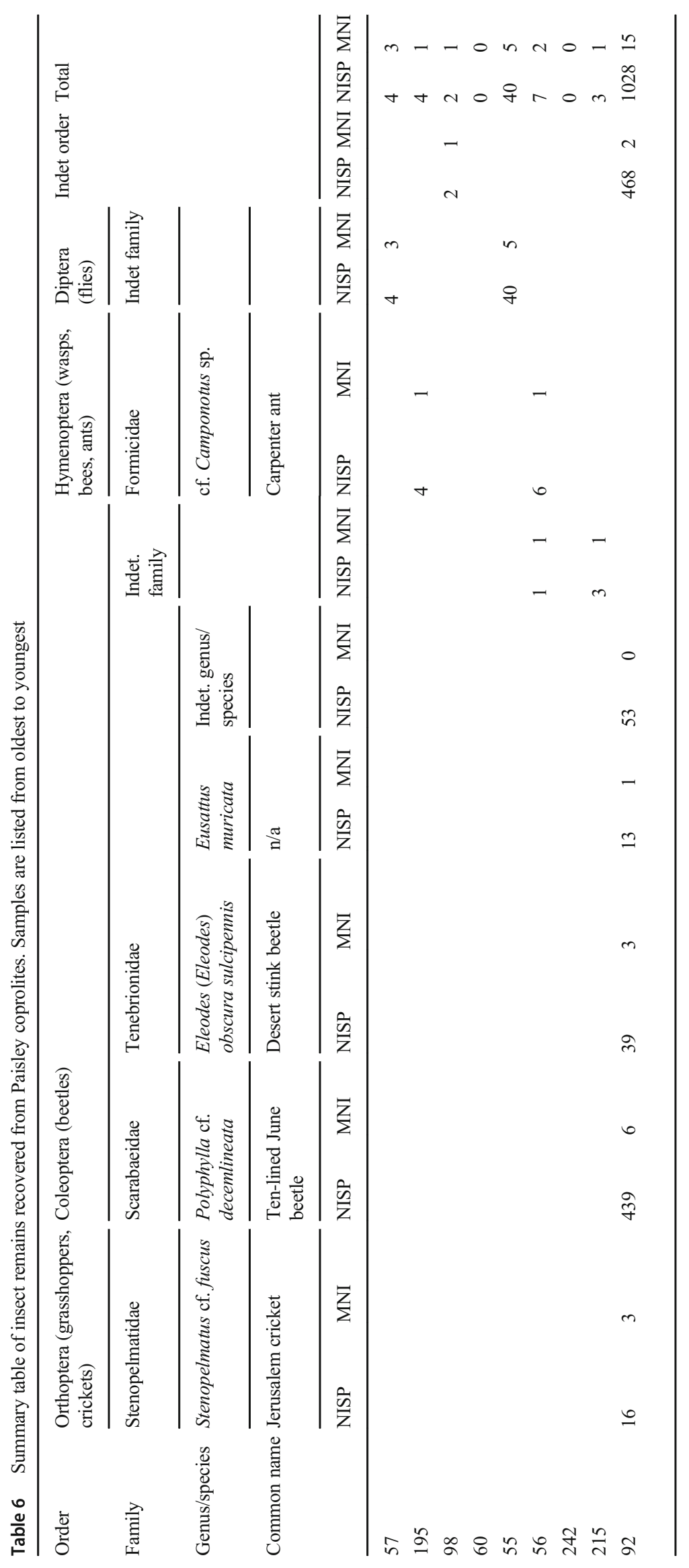


Fig. 10 Bar chart showing insect MNI in each coprolite

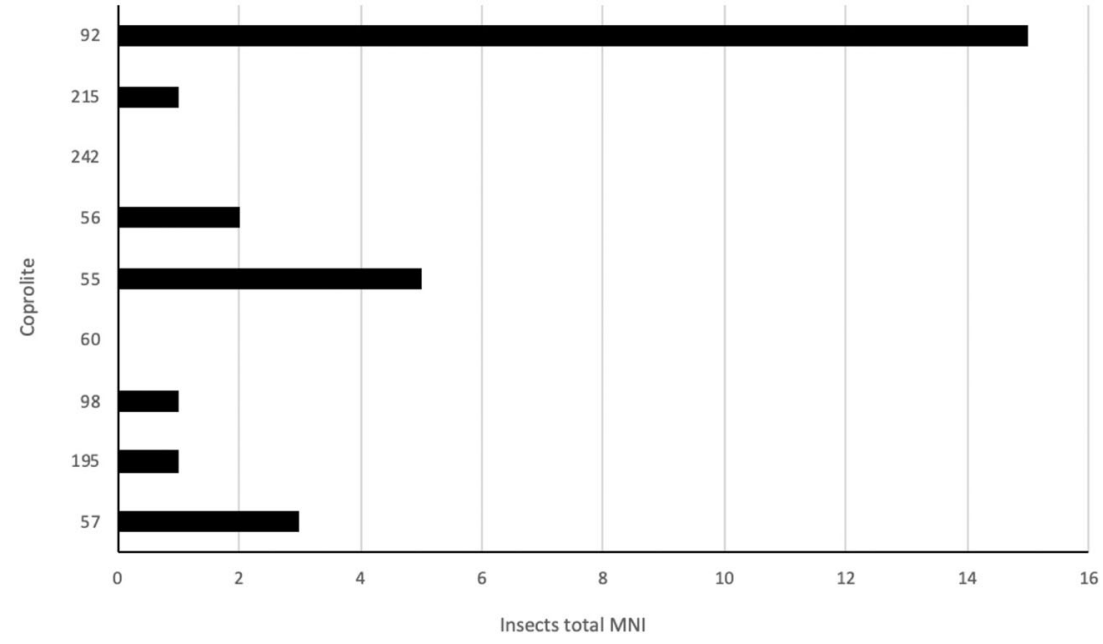

\section{Discussion}

The multiproxy macro and microscopic analyses presented in this study provide new data on YD/EH diet, season of occupation, and land-use patterns during the WST occupation at Paisley Caves in the northern Great Basin. This study presents a relatively small data set considering the 2000 years of occupation represented by the coprolites but provides crucial data for this poorly represented time period. As data improves both from the Paisley Caves and other sites in the region, we will have the opportunity to further explore ongoing debates about WST diet and land use.

\section{Human origin of coprolites}

During rehydration, coprolites $92,215,242,56,55,60$, and 98 turned the sodium phosphate solution opaque to semi-opaque with colors ranging from black to dark brown - consistent with human origin (Bryant 1974b). These seven coprolites contained a variety of plant macrofossils and animal bone suggesting an omnivorous diet. Coprolites 56, 92, and 215 had insect remains further representing an omnivorous diet, and all but 92 and 215 contained charcoal suggesting cultural food preparation. These characteristics led to the interpretation that humans deposited these seven coprolites. Sample 215 was previously found to contain Homo sapiens haplogroup A mtDNA (Jenkins et al. 2012), and recent fecal biomarker analysis has confirmed that this coprolite was deposited by a human (Shillito et al. 2020b).

During the rehydration process, coprolite 195 turned the sodium phosphate solution translucent and dark yellowishbrown - consistent with carnivore or herbivore origin (Bryant 1974b). The macrofossils recovered from coprolite 195 consist primarily of unidentified plant fiber; no seeds or charcoal were present in the analyzed sample. Pollen data indicate consumption of legume family flowers, and the phytolith data suggest the consumption of a high amount of monocot and dicot vegetation relative to the other coprolites. The coprolite also contained two small fragments of bone suggesting an omnivorous diet. Coprolite 195 was previously identified as human based on the presence of Homo sapiens haplogroup B2 mtDNA, though it also contained Canis lupus/ familiaris mtDNA (Gilbert et al. 2008). Fecal biomarker analysis of coprolite 195 indicates the presence of fecal material from both human and carnivore sources suggesting coprophagy (Shillito et al. 2020b). The macrofossil and microfossil evidence suggest an omnivorous human-like diet, and the coprolite has very little hair or bone as would be expected in a carnivore coprolite. We do not expect that humans were consuming carnivore feces. It is possible that coprolite 195 represents feces deposited by a carnivore that consumed a meal consisting of human feces, in which case it still represents a record of human diet.

During the rehydration process, coprolite 57 also turned the sodium phosphate solution translucent and dark yellowish brown consistent with carnivore or herbivore origin. However, this coprolite contained a variety of plant material including plant fiber, cattail seed, phytoliths from dicot leaf material, and charcoal, as well as animal bone indicating the consumption of rabbit/hare. These constituents suggest an omnivorous diet and human origin for this coprolite and support research indicating that rehydrated color is not always an accurate indicator of herbivore, carnivore, or human origins (Reinhard and Bryant Jr 1992). Based on the characteristics described here we, are interpreting the nine coprolites in this study to be of human origin; this will be confirmed through forthcoming fecal biomarker analysis.

\section{YD and EH diets}

All nine coprolites in this study contained a mix of plant and faunal remains, though in varying proportions. Not all items that enter the human digestive system are necessarily linked to dietary consumption, some remains likely represent unintentional or incidental consumption. Sample 242 contained an angular pebble spall with the 
Fig. 11 Insect taxa identified in the Paisley Caves coprolites: a remains of the ten-lined June beetle (Polyphylla $\mathrm{cf}$. decemlineata) recovered from coprolite 92: (A and B) frontal view of two head fragments; (C) dorsal view of the apex of a pronotum fragment and attached scutellum; (D) tibia and three attached tarsomeres of a foreleg; and (E) articulated femur, tibia, and three tarsomeres of a mid-leg; b remains of Eleodes obscura sulcipennis recovered from coprolite 92: (A) unsided elytrum fragment; (B) posterior fragment of the right elytron; and $(\mathrm{C})$ dorsal view of the head; $\mathbf{c}$ two unsided elytra fragments of Eusattus muricatus recovered from coprolite 92 a
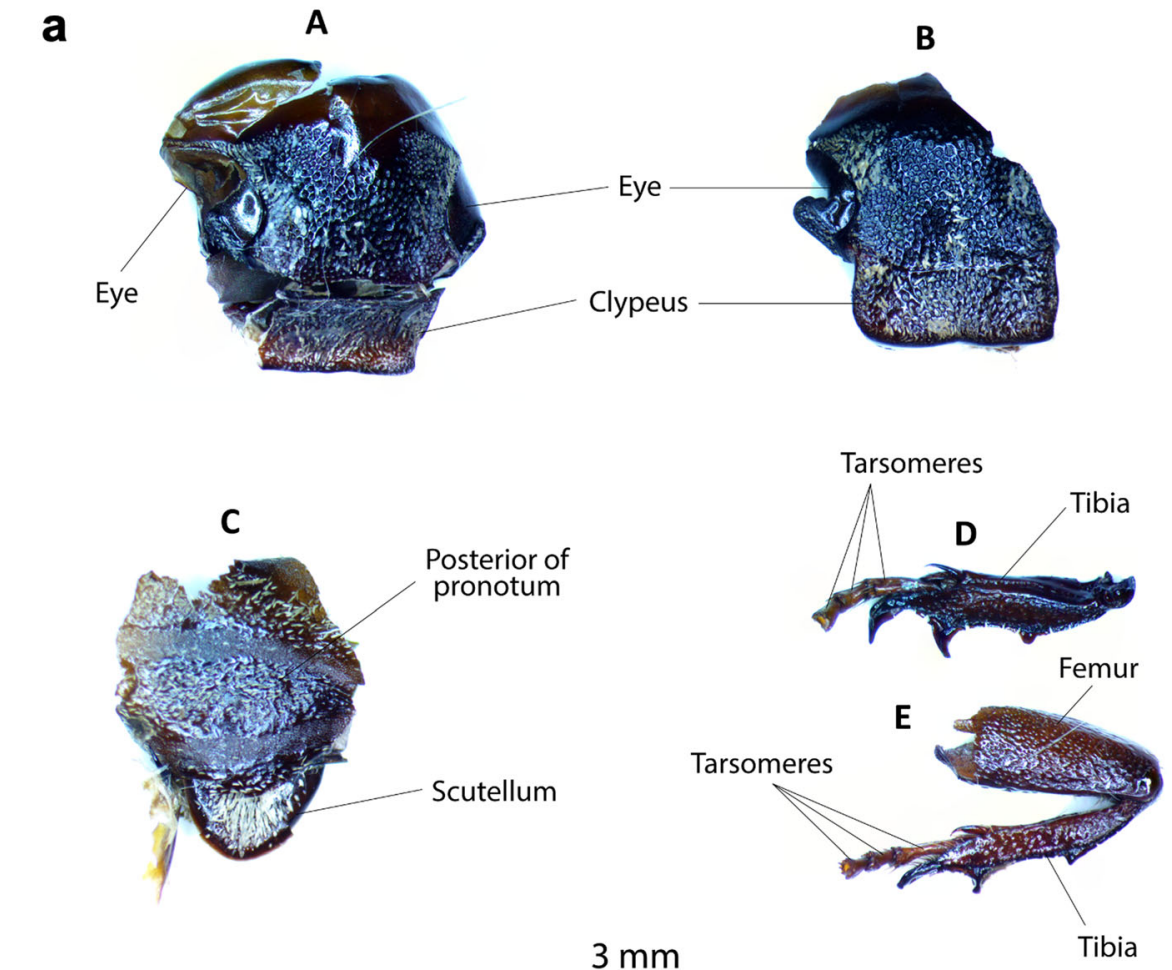

$3 \mathrm{~mm}$
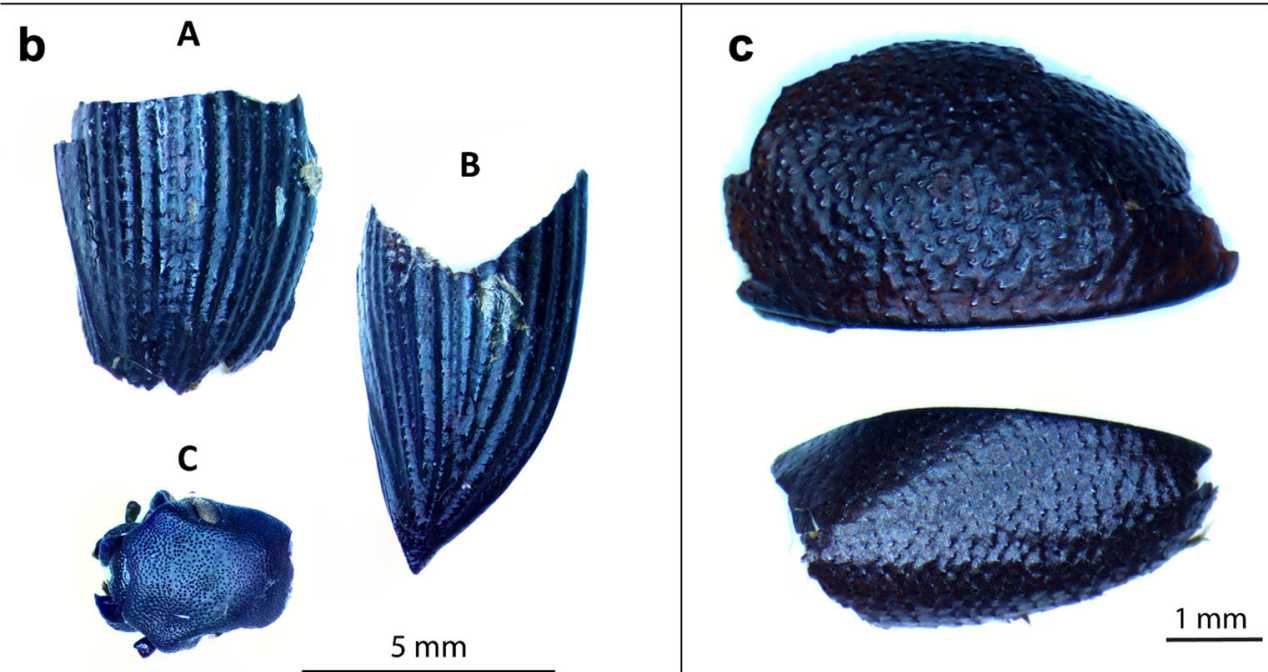

appearance of thermally fractured rock, possibly linked to stone cooking techniques. Sample 215 contained a very small obsidian retouch chip likely from hunting/ processing tools. Small quantities of feathers and hair may also represent incidental consumption. Jenkins et al. (2016) suggest that food preparation at the Paisley Caves occurred on mats placed on the floor of the caves, which is a possible explanation for the introduction of material such as sediment, stone, hair, and feathers into foods prepared and consumed in the caves.

Bone inclusions in coprolites are likely to represent intentional consumption of meat. The faunal record provides evidence for consumption of small/medium and very small mammals, as well as birds and fish. The latter are represented by a single incidence of Catostomidae/Cyprinidae vertebra, indicating some use of lacustrine or riparian resources, likely procured from Summer Lake, the Chewaucan River, or Upper Chewaucan Marsh. Bone and feathers in coprolite 242 and feathers in coprolite 98 indicate bird was consumed, but more detailed taxonomic information is not available due to the absence of diagnostic skeletal elements. The small number of feathers in coprolite 56 provides moderate confidence of bird consumption but may represent accidental consumption. Notably, none of the bones in this study appear to have been 


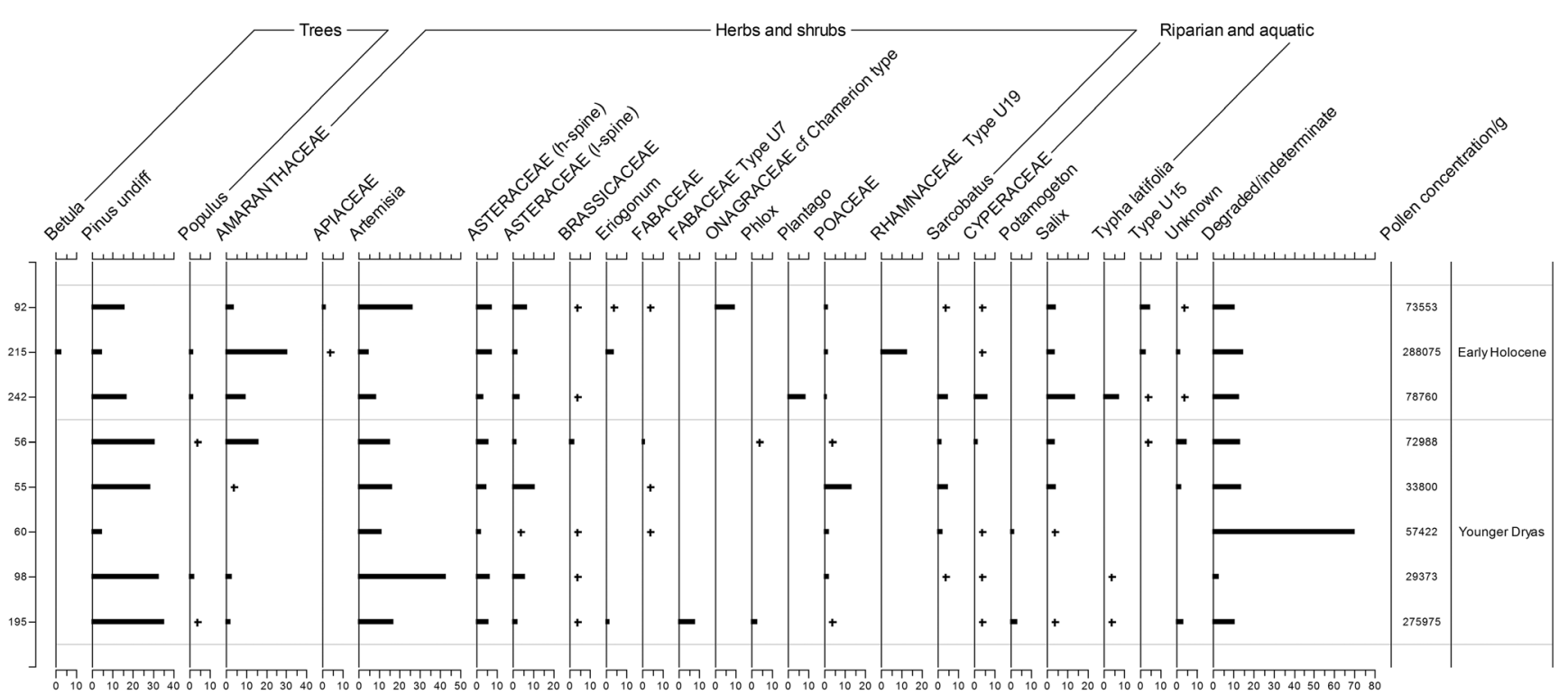

Fig. 12 Summary diagram of pollen relative frequencies for each taxa identified in this study. "+" indicates taxa present in frequency of $1 \%$ or less. Complete pollen data is presented in the supplementary material (Online Resource 1)

altered by cooking. The small, fragmented nature of the faunal assemblage precludes any in-depth interpretation of this observation, but future research may be able to infer food preparation methods from larger data sets like this.
Two coprolites provide evidence for consumption of hare/jackrabbit and small/medium mammal likely to be rabbit or hare. This supports previous studies suggesting that leporids were a common YD/EH dietary item at the Paisley Caves (Hockett et al. 2017; Taylor et al. 2019). Faunal

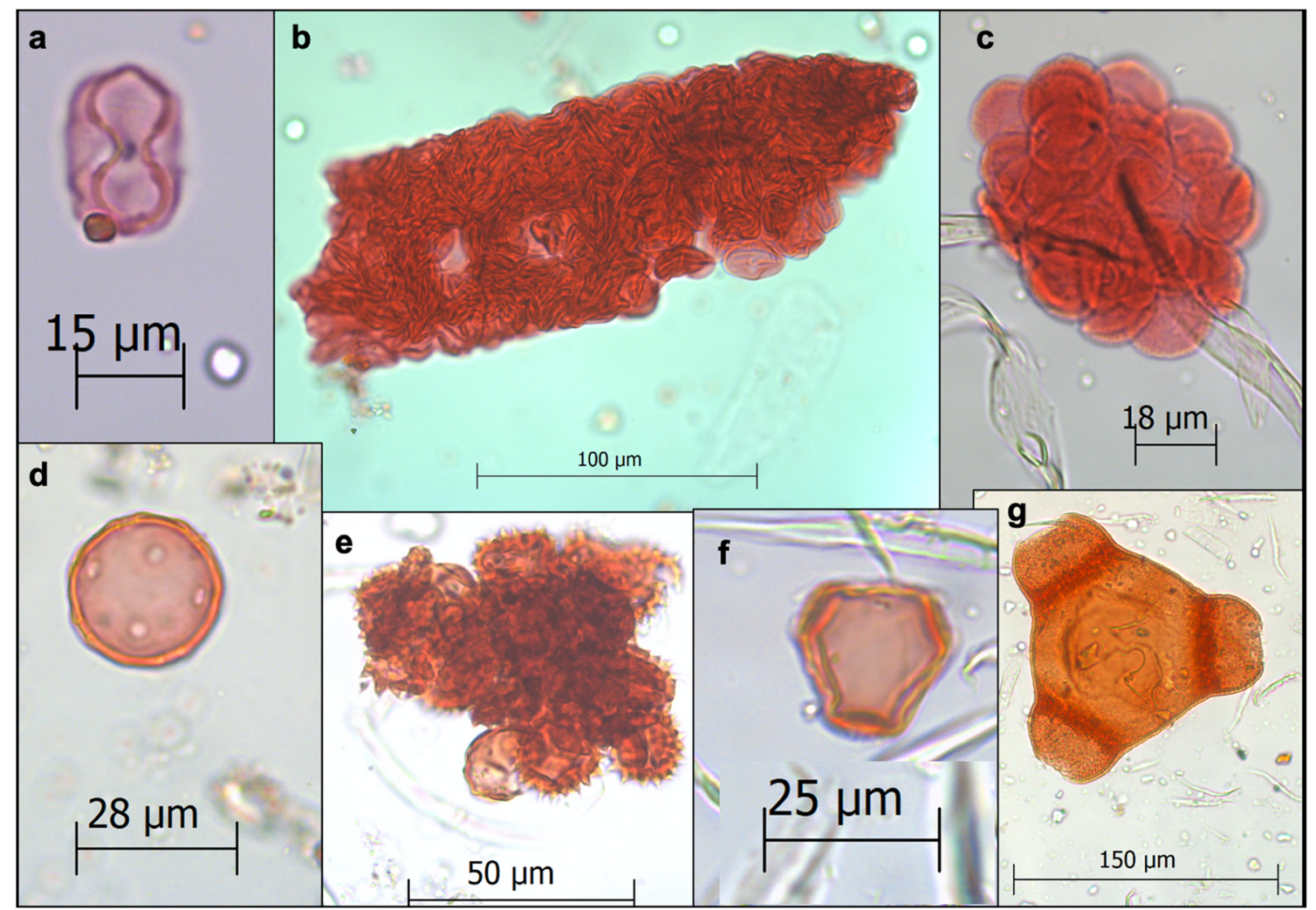

Fig. 13 Pollen grains identified in the Paisley Caves coprolites: a coprolite 195 Fabaceae type U7, b coprolite 195 Fabaceae type U7 anther aggregate, $\mathbf{c}$ coprolite 98 Typha latifolia aggregate, $\mathbf{d}$ coprolite
242 Plantago sp., e coprolite 215 low-spine Asteraceae aggregate, f coprolite 215 Rhamnaceae type U19, g coprolite 92 Onagraceae cf. Chamerion type 


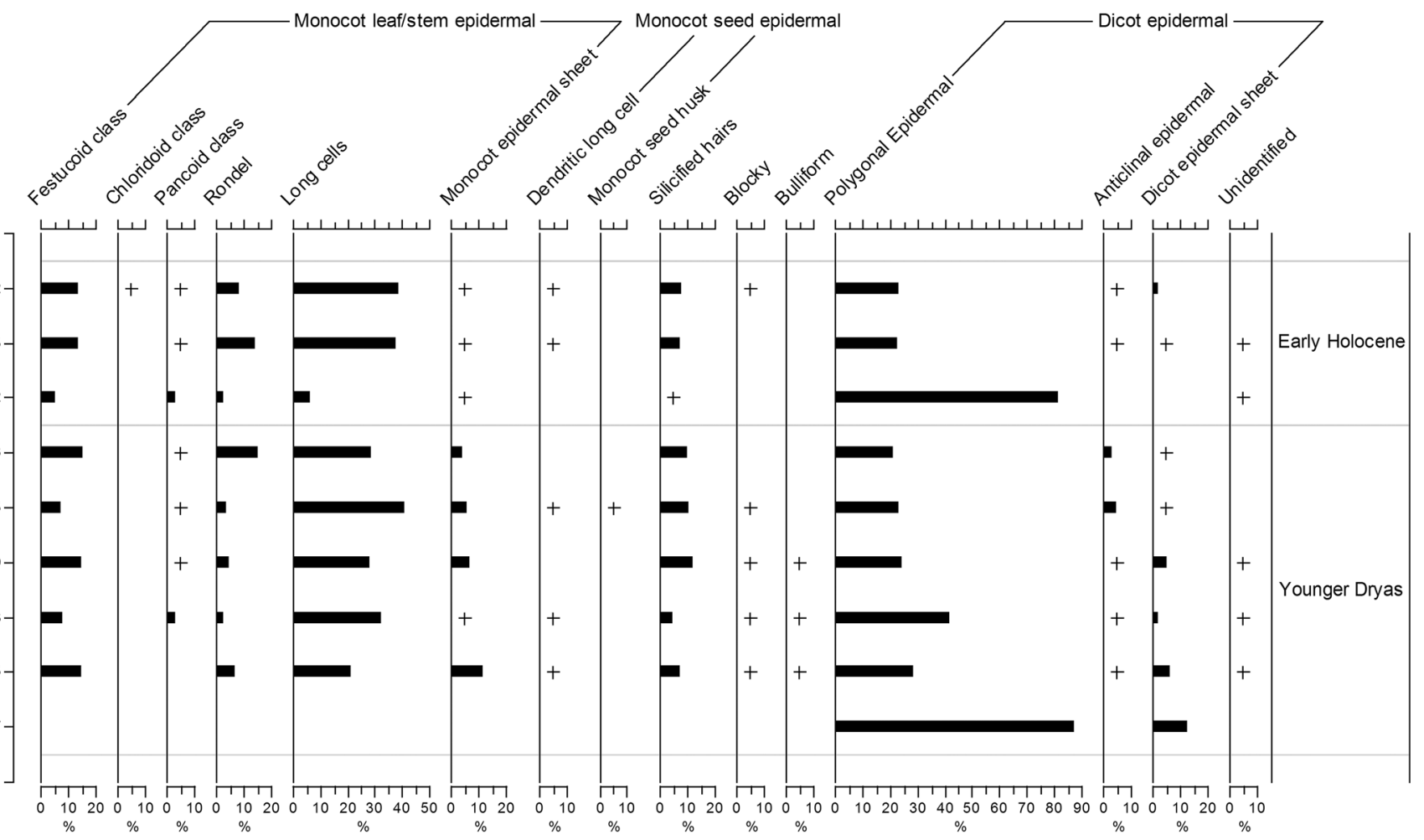

Fig. 14 Summary diagram of phytolith frequencies for each morphotype categories identified in this study. Frequencies are calculated as percent of total phytolith counts (single + conjoined with each conjoined sheet

counted as one). “+” indicates morphotype category present in frequency of $2 \%$ or less. Complete phytolith data is presented in the supplementary material (Online Resource 1)

remains from rodent and rodent-sized mammal are present in two coprolites. The presence of rodent vertebra, phalanges, and corpus unguis along with animal hair in coprolite 56 suggests consumption of whole rodents including appendages, skin, and fur. Rodent consumption has been previously documented in ethnographic accounts and Holocene

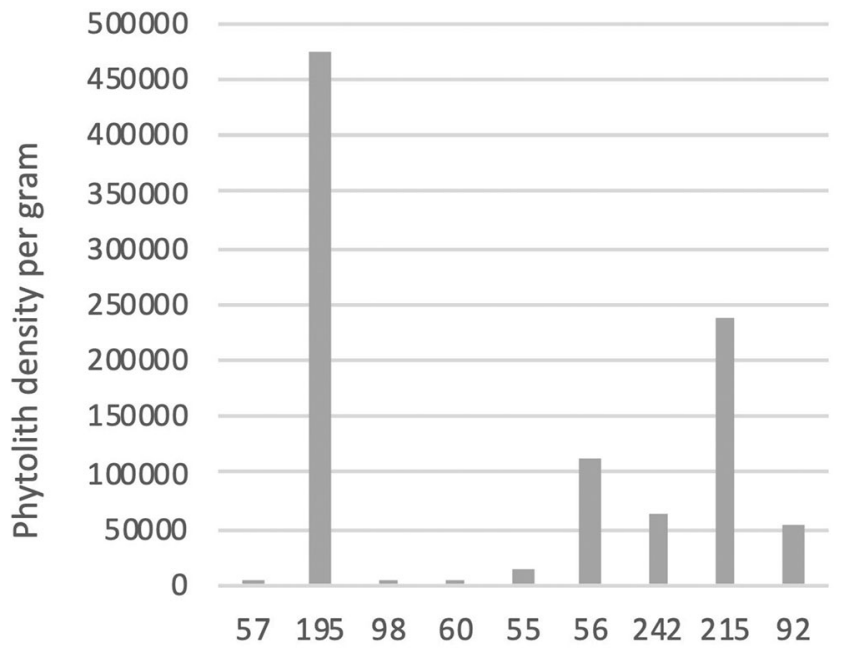

\section{Coprolite sample}

Fig. 15 Bar chart showing estimated phytolith density per gram of coprolite material archaeological contexts in the Great Basin (Fowler 1986; Fry 1976; Reinhard et al. 2007), including in early and late Holocene occupations at the Paisley Caves (Taylor et al. 2019). Our analysis is the first study to present direct evidence for rodent consumption in the YD occupation of the Paisley Caves and, to our knowledge, for the broader northern Great Basin.

The faunal NISP is highly variable ranging from 2 to 248 ; two coprolites with high NISP have faunal material from fish (60) and rodent (56), suggesting a link between NISP and consumption of small animals that should be explored with larger data sets. Sample 98 has the largest NISP and largest initial sample weight, so faunal NISP may in some cases simply be correlated to sample size. NISP also likely reflects the variable impact of food processing and digestion (O'Meara 2014). Most of the faunal material can only be identified with coarse taxonomic resolution potentially masking the diversity of animal species consumed during the $\mathrm{YD} / \mathrm{EH}$.

Insect remains are linked to intentional consumption based on previous archaeological and ethnographic research, the behavior of the taxa identified, and the MNI and condition of the remains represented in the coprolite. All high-confidence evidence for consumption of insects comes from EH coprolite 92. The observation of the tenlined June beetle remains is unique; this species has not been identified in previous studies of insect remains 
Fig. 16 Bar chart showing percent contribution of conjoined phytolith morphotype categories
Conjoined phytoliths

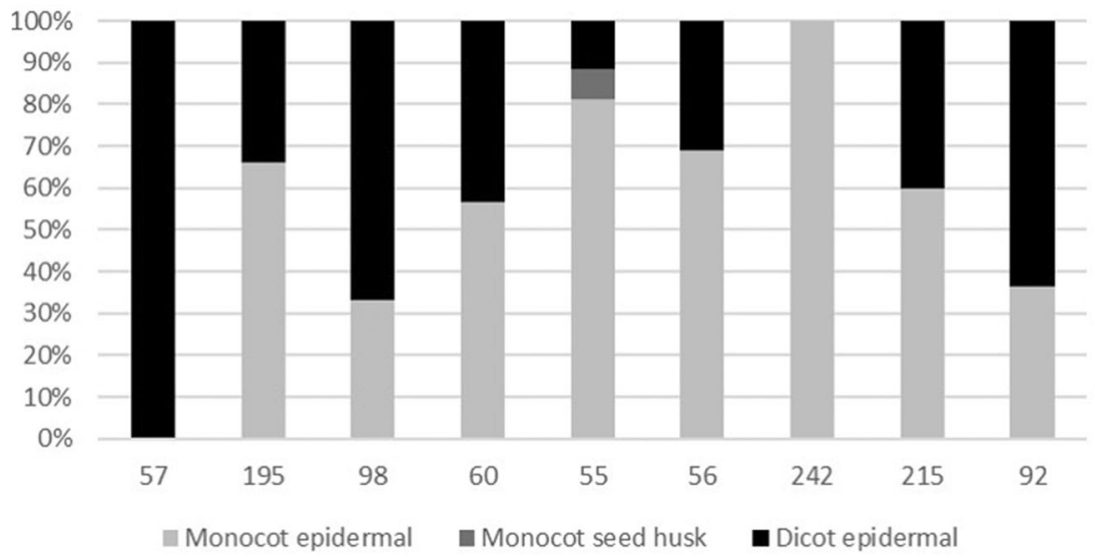

recovered from archaeological contexts at the Paisley Caves (Adams, unpublished data; Hockett et al. 2017). This beetle is widespread in western North America; the larval period can last from 2 to 4 years, but the adult stage is relatively short, usually from late June to early October (Beers et al. 1993). Consumption of roasted adult June beetles is documented ethnographically by groups such as the Bear River Shoshone and Northern Paiute groups in California (Nomland 1938; Sutton 1988). Ten-lined June beetles are a relatively large species; they are attracted to lights and these particular specimens may have been caught and eaten after flying toward a campfire (Young 1988).

Jerusalem cricket remains have previously been recovered in YD-aged deposits at the Paisley Caves and were likely a common component of YD and EH diet (Hockett et al. 2017). Jerusalem cricket nymphs usually appear in the fall and can take up to 2 years to reach full maturity (Ebeling 1986). Jerusalem cricket remains are plentiful throughout the cave 2 insect assemblage (Adams, unpublished data). The use of Jerusalem crickets as a food source at the Paisley is unique as there is little or no evidence in the literature that supports

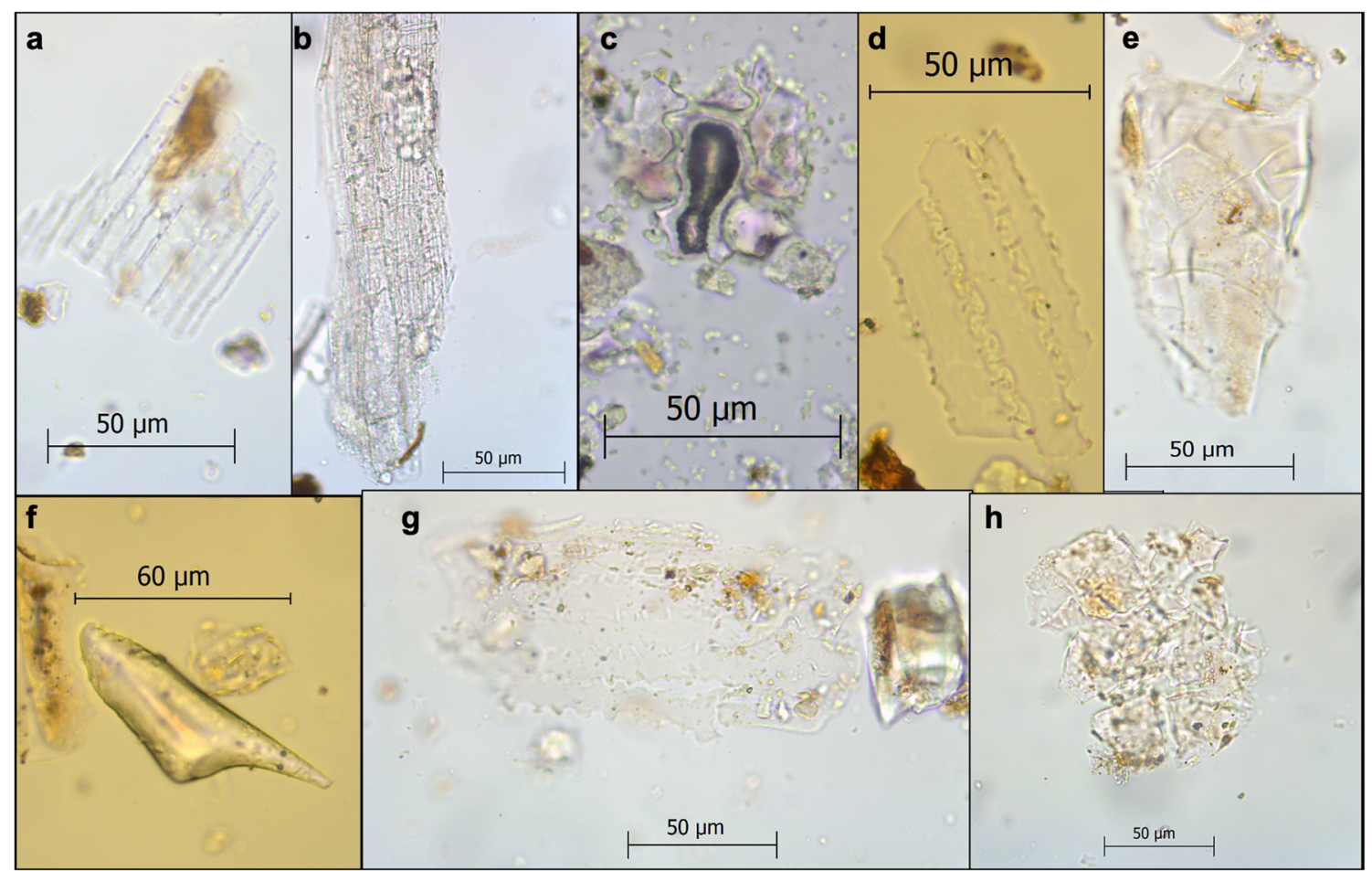

Fig. 17 Phytolith morphological types identified in the Paisley Caves coprolites: a coprolite 55 monocot epidermal sheet, b coprolite 60 monocot epidermal sheet, c coprolite 215 dicot epidermal sheet, d coprolite 55 monocot seed husk sheet, e coprolite 98 dicot epidermal sheet, $\mathbf{f}$ coprolite 98 trichome, $\mathbf{g}$ coprolite 195 monocot epidermal sheet, h coprolite 57 dicot epidermal sheet 
them being a food source for Native peoples anywhere else in the Great Basin. While Mormon crickets (Anabrus simplex) tend to be a common insect food item when discussing Great Basin insect consumption (Ebeling 1986; Sutton 1988, 1995), preliminary analysis of the Paisley Cave 2 insect fauna indicate the abundance of Jerusalem crickets dominates that of Mormon crickets by a factor of 12 (Adams, unpublished data).

Darkling beetle remains are present in large quantities in the Paisley Caves deposits, and many members of this family are specifically adapted to living in arid environments such as those in the Great Basin. Both Eusattus muricatus and Eleodes obscura sulcipennis are generalist herbivores and scavengers (Aalbu et al. 2002; Doyen 1984) and may be attracted to fresh feces for its water content. The condition of both species in this assemblage, however, suggests they were most likely chewed and swallowed. The presence of Eusattus muricatus is not unexpected, as the remains of dozens of E. muricatus specimens have been recovered from the cave 2 deposits and it would appear they were quite plentiful (Adams, unpublished data). The presence of Eleodes obscura sulcipennis is, on the other hand, unusual. The common name for all members of the genus Eleodes is the "desert stink beetle," so named because these beetles possess a stink gland that is used to ward off potential predators and they have a reputation for being distasteful. However, the desert stink beetle does have medicinal uses among some arid-dwelling people, most notably the Navajo (Wyman and Bailey 1964), so human consumption may be linked to medicinal use.

Coprolites 56 and 215 contained remains of individuals from the order Coleoptera and may represent additional examples of intentional insect consumption similar to those documented in coprolite 92; however, these remains occur in low frequency and can only be attributed to intentional consumption with moderate confidence. Without higher-resolution identification, postdepositional intrusion into the coprolite by coprophagous beetles cannot be ruled out. Ant remains in coprolites 56 and 195 may represent intentional consumption, but the low frequency suggests accidental consumption or postdepositional intrusion into the coprolite. Coprolites 55 and 57 contained larval fly (maggot) puparium fragments. These likely represent postdepositional intrusion by larvae hatched from eggs deposited on the feces by small unidentified flies.

Seeds from seven identified and two unidentified taxa were recovered in the coprolites, although in small quantities, and evidence for seed consumption is more common in EH coprolites than YD coprolites. Seeds were likely processed prior to consumption to aid in digestion; this coupled with further breakdown during digestion likely resulted in a small number of surviving seeds relative to the number of seeds ingested (Reinhard and Bryant 2008). The Paisley coprolites provide evidence for consumption of wild rose, tansy mustard, cattail, grass, amaranth, and sedge seeds and fruits. Wild rose, tansy mustard, cattail, grass, and amaranth seeds and fruits recovered from YD/EH archaeological deposits at the Paisley Caves have been previously linked to human diet (Kennedy 2018, p. 283). Our study provides direct evidence supporting previous research and offers insight that sedge seed may also have been a component of human diet during the WST occupation of the caves.

Seeds such as cattail with low MNI are interpreted to represent intentional consumption in this study. However, this needs to be further explored in forthcoming analyses of additional coprolites from this time period. Northern Paiute populations in the Great Basin harvested cattail seeds, flash burned the seeds to remove the seed fluff and toast the seeds, then winnowed and aggregated the seeds to consume in large quantities (Fowler 1986; Kelly 1932). Middle to late Holocene coprolites from the Connley Caves (5700 to $3200 \mathrm{cal} \mathrm{BP}$ ) in the northern Great Basin contained more than 1000 cattail seeds per gram of coprolite (McDonough 2019), likely representing similar processing and consumption to that described in the ethnographic literature. The low frequency and lack of charring of cattail seeds in the Paisley Caves samples does not appear to represent intensive cattail seed consumption. However, seed-sized food remains can be passed gradually through the human digestive system over the course of several days to weeks after initial ingestion (Alvarez and Freedlander 1924). The small number of cattail seeds recovered might therefore be the remnants of a meal consumed several days prior to deposition of the analyzed coprolites. This example highlights the need to carefully consider cultural and biological processes when interpreting dietary inputs from macrofossil remains (Shillito et al. 2020a). The lack of evidence for charring/cooking in seeds recovered from the Paisley Caves coprolites is interesting; it may be that uncharred, intact seeds were less impacted by the digestion process and preferentially preserved, or it might reflect food processing/preparation techniques that did not expose seeds to high heat in a reduced atmosphere (e.g., Märkle and Rösch 2008).

The phytolith record provides evidence for consumption of monocot and/or dicot plant material in each coprolite analyzed for this study. This indicates that plant material—primarily leaf epidermis - was consumed with all meals. Variable phytolith density between samples suggests differences in the proportion of plant material in the diet. A high frequency of monocot morphotypes including a small number of dendritic types is linked with pollen evidence for consumption of grass in coprolite 55, suggesting consumption of grass plant material in the summer or fall after flowering when the plant was producing seed. A relatively high frequency of dicot epidermal morphotypes is linked with amaranth family seed in coprolite 98 , suggesting the consumption of amaranth family leaf material. With the exception of coprolite 195 , there is an 
increase in phytolith density in the four youngest coprolites spanning the late YD and EH possibly linked to increased consumption of plant resources. However, this needs to be further explored with larger data sets. Consumption of leaf epidermal material is an underappreciated aspect of huntergatherer diet. Most research focuses on nutrients that come from meat, seeds, and underground storage organs (roots and tubers). Our study suggests that leafy greens are an important component of the $\mathrm{YD} / \mathrm{EH}$ diet.

The coprolite pollen data supports with high confidence the intentional consumption of legume, buckthorn, and evening primrose plant material. Legume family taxa are entomophilous, and the high frequency, concentration, and large aggregates in coprolite 195 clearly indicate the consumption of Fabaceae flowers. Plants in the buckthorn and evening primrose families are entomophilous-pollinating, and coprolites 215 and 92, respectively, contained high frequencies of pollen types from these families indicating intentional consumption. Three of the seven seed types identified in the macrofossil sample (cattail in coprolite 242, amaranth in coprolite 215, and sedge in coprolite 242) contained corresponding pollen in high frequency, concentration, and with aggregates (in 215), providing multiproxy evidence for consumption of these taxa. The other four seed types did not have pollen frequencies corresponding with the presence of seeds, possibly explained by the manner in which these seeds were prepared.

We find support with moderate confidence for intentional consumption of pondweed, sagebrush, cattail, willow, plantain, wild buckwheat, and aster family plant material. These taxa fit some criteria for intentional consumption, but ingestion from nondietary sources cannot be ruled out. For example, Rhode and Louderback (2007) suggest that flowering heads of cattail may have been used as a fire starter during WST occupation of Bonneville Estates Rockshelter. As noted above, the botanical lens in the Paisley Caves consists primarily of sagebrush matting. Collecting these materials and bringing them into the caves may have exposed individuals to increased amounts of pollen resulting in higher than expected levels in their feces.

Taylor et al. (2019) examined pollen, plant macrofossils, bone, and hair from eleven YD/EH Paisley Caves coprolites, including subsamples of three coprolites analyzed for this study (coprolites 55, 56, and 57). Notably, there are significant differences in plant macrofossil recovery and pollen frequency/concentration in subsamples from the same coprolite, adding support to research documenting variability in dietary records from samples taken at different locations of the same coprolite (Beck et al. 2019; Martin and Sharrock 1964). Taylor et al. (2019) conclude that diets leaned toward animal resources, primarily lagomorphs but also bighorn sheep (Ovis canadensis) and rodent (in EH contexts), with limited evidence for consumption of plant foods and no evidence for season of occupation. Our study confirms that lagomorphs were consumed in the $\mathrm{YD}$, and pushes back secure evidence for rodent consumption into the YD. We found stronger evidence in the plant macrofossil, pollen, and phytolith records for consumption of plant material. Our results demonstrate that the most complete record is derived from combined multiproxy studies. These results support previous research indicating that as many as 20 coprolites from an archaeological context need to be analyzed to capture the full range of dietary diversity (Reinhard and Bryant 1992).

\section{Seasonality and land-use variability at the Paisley Caves}

Information on the life cycle and ecological distribution for the plant and animal remains in Table 3 can be used to estimate season of occupation and the ecological zones being exploited by WST occupants of the Paisley Caves. This study assumes that plants and animals recovered from the coprolites presented here were consumed in the season that they were harvested because WST sites in the northern Great Basin provide little evidence for food storage (Smith and Barker 2017; but see Connolly and Jenkins 1999, p. 103).

Our study found that wetland resources are represented in eight of the nine samples, while dryland resources are represented in four. The animals and insects represented in the Paisley coprolites are somewhat less ecologically restricted than plant taxa. However, these data can provide some additional insight to land-use patterns. Small mammals such as rodents occur in greater density in wetlands and may have been targeted here (Simms 2008, p. 41). Hare/jackrabbit was likely hunted in the sagebrush steppe grasslands as documented in the ethnographic record (Fowler 1986). Some of the taxa identified in this study do not provide relevant information on land-use patterns; for example, grass, plantain, and buckwheat are very diverse families, and species from these taxa grow in a variety of ecological zones.

The record of plant and animal resources documented in the Paisley Caves coprolites provides preliminary evidence for site occupation focused in the summer and fall, but with some potential indications of spring and winter occupation (Fig. 18). Our study largely supports previous research suggesting that the caves were occupied in the spring or late summer/fall (Jenkins et al. 2016; Kennedy 2018). Jenkins et al. (2016) link seasonal occupation to periods of resource abundance. However, our study does not find evidence for any one resource dominating the coprolite record, as would be expected if individuals were binging on seasonally available resources (Reinhard 1993). Instead, occupants of the caves appear to have been eating a wide variety of resources.

Evidence for seasonal use suggests that the Paisley Caves was occupied on a short-term basis as part of a broader seasonal round as noted by Jenkins et al. (2016). This offers a point of contrast to studies suggesting YD/EH occupations 

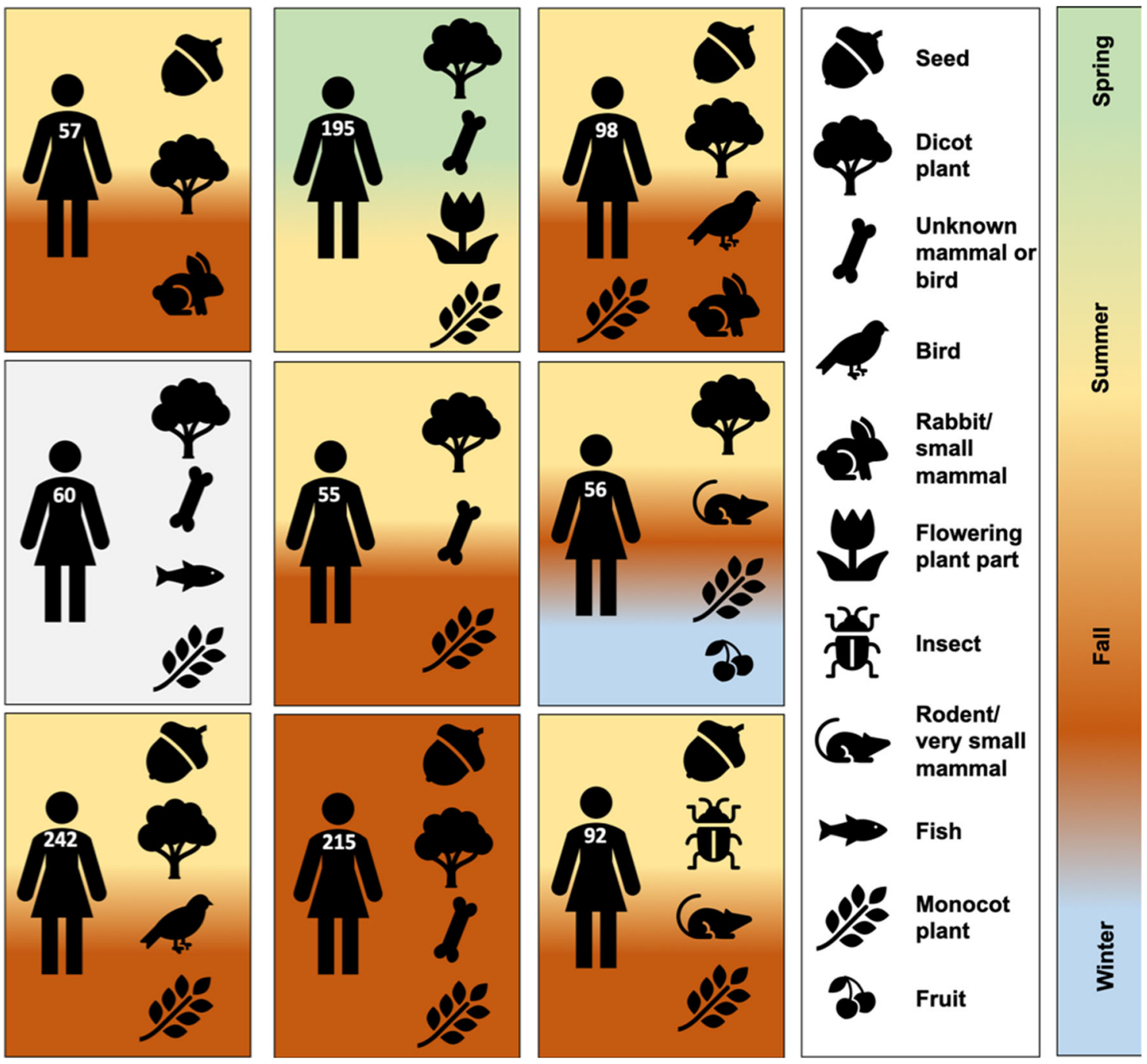

Fig. 18 Qualitative summary of dietary items with high confidence of consumption in the Paisley coprolites analyzed for this study, with estimates of likely seasonality

near wetlands were typically longer-term residential camps (e.g., Smith and Barker 2017). We present evidence for subsistence forays to a variety of ecological landscapes surrounding the caves, indicating that the wetlands below the cave likely attracted people to the Paisley Caves, but were not always the primary focus for subsistence activities. These questions of seasonality and land use are still outstanding and need to be explored further with larger data sets.

The results of this study inform on our understanding of the process of the peopling of the Americas. The WST in western North America appears to be co-eval with or may predate Clovis, so WST subsistence-settlement systems provide insight into adaptative strategies used during the spread of humans across North America. Our results indicate that YD and EH WST inhabitants of the northern Great Basin utilized a variety of local plant and small mammal resources and were not necessarily focused on large mammals for subsistence.
WST inhabitants had a "settled in" seasonal subsistence strategy centered on wetland and riparian resources. This study does not present data from the earliest Bølling-Allerød WST occupations of western North America; however, our research suggests this pattern was well-established by the YD and likely reflects a similar adaptation practiced by the initial occupants of the Great Basin. This contrasts with our understanding of the initial settlement of North America described in the Clovis model, characterized by people trekking long distances across the continent following large mammal populations (Kelly and Todd 1988).

\section{Conclusion}

The multiproxy results presented in this study found strong evidence to support a diverse diet in the northern Great Basin 
during the YD and EH. Western Stemmed Tradition occupants of Paisley Caves 2 and 5 clearly consumed a variety of small mammal, plant, and insect food resources. This study provides the earliest examples of whole rodent consumption and the first direct evidence for consumption of ten-lined June beetle and desert stink beetle in the northern Great Basin. Our study complements existing plant and animal data sets derived from sedimentary contexts at the Paisley Caves and adds clarity to human dietary decisions during a period with sparse direct evidence. The combined data support models proposing a broad-based subsistence strategy in the northern Great Basin during the WST and suggest that studies focused on evidence for a narrower diet breadth in terminal Pleistocene North America may be missing important subsistence diversity. Well-preserved remains at the Paisley Caves offer an opportunity to examine Pleistocene subsistence strategies in a setting that has not been impacted by issues of sampling and taphonomy that may have preferentially preserved evidence for large mammal hunting at other Pleistocene-aged sites (e.g., Cannon and Meltzer 2004, 2008).

The results of this study offer support for occupation of the caves during the summer and fall, by individuals foraging on wetland, sagebrush grassland, and riparian landscapes. The evidence supports seasonal occupation of the caves but finds that occupation may not have always been focused on harvesting resources available in abundance (c.f., Jenkins et al. 2016). Wetland food resources were important during the WST occupation of the Paisley Caves, but occupants of the caves exploited a broad range of ecological landscapes. As Jenkins et al. (2016) note, receding lake levels in the YD and EH appear to have provided a productive mosaic of ecological niches that were exploited by occupants of the Paisley Caves. This new data provisionally supports previous research indicating that Pleistocene inhabitants of western North America had a broad-based diet and wetland/riverine adaptation, potentially linked to an initial coastal migration (Davis et al. 2012; Erlandson et al. 2015; Madsen et al. 2015). Moving forward, our research will seek to explore explanations for the inclusion of seemingly low-calorie resources and the relative frequency of this type of food in a larger sample set. In doing so, we will be able to address questions of human dietary choice, specifically the role of maximizing caloric gain versus nutritional needs and cultural preferences.

Our multiproxy approach provides novel observations on diet through individual analytical techniques. These results highlight the need for multiproxy analyses to present a more robust picture of human diet (Shillito et al. 2018; Shillito et al. 2020a). Coprolites provide direct evidence of human consumption that can be used to both compliment and clarify faunal and plant material recovered from archaeological sediments. Our ongoing study will integrate these lines of evidence for a holistic view of human diet and land use throughout the sequence of human occupations at Paisley Caves.
Acknowledgments We would like to thank Paul Wolf and Michael B. Piep at the Utah State Intermountain Herbarium and Mitchell J. Power and Elizabeth Johnson at the University of Utah Garrett Herbarium for access to their reference collections; Dave Catania and Mysi Hoang (California Academy of Sciences, San Francisco, California) and Chris Conroy, Carol Spencer, and Carla Cicero (Museum of Vertebrate Zoology, University of California, Berkeley) for their aid in accessing the osteological comparative collections. Thank you to Katelyn McDonough, Chase Beck, and Vaughn Bryant (Texas A\&M University) for their assistance with pollen identification. Thank you to James Patton and Christopher Conroy (Museum of Vertebrate Zoology, University of California, Berkeley) for their assistance in the identification of rodents from the families Heteromyidae and Cricetidae. Eline van Asperen (Newcastle University) provided assistance with sample processing, and Jacqueline Cooper (University of California, Berkeley) provided assistance cataloging the faunal remains reported. Thank you also to Thomas W. Stafford and the excavation team at the Paisley Caves for their important contributions. Finally, we are grateful for the comments we received from two anonymous reviewers; their careful attention significantly improved this manuscript.

Funding information This project is funded by the Natural Environment Research Council Grant, reference number NE/P003001/1, and the Natural Environment Research Council Radiocarbon Facility Award, reference number NF/2018/2/18.

Open Access This article is licensed under a Creative Commons Attribution 4.0 International License, which permits use, sharing, adaptation, distribution and reproduction in any medium or format, as long as you give appropriate credit to the original author(s) and the source, provide a link to the Creative Commons licence, and indicate if changes were made. The images or other third party material in this article are included in the article's Creative Commons licence, unless indicated otherwise in a credit line to the material. If material is not included in the article's Creative Commons licence and your intended use is not permitted by statutory regulation or exceeds the permitted use, you will need to obtain permission directly from the copyright holder. To view a copy of this licence, visit http://creativecommons.org/licenses/by/4.0/.

\section{References}

Aalbu RL, Triplehorn CAJ, Campbell M, Brown KW, Somerby RE, Thomas DB (2002) Tenebrionidae Latreille 1802. In: Ross HA Jr, Thomas MC, Skelley PE, Frank JH (eds) American beetles, volume 2 - Polyphaga: Scarabaeoidea through Curculionoidea. CRC, Boca Raton, pp 463-509

Adams ME, Jenkins DL (2017) An Early Holocene record of Cimex (Hemiptera: Cimicidae) from western North America. J Med Entomol 54:934-944. https://doi.org/10.1093/jme/tjx057

Adams ME, Jenkins DL (2020) Earliest record of the spinose ear tick, Otobius megnini (Dugès) (Ixodida: Argasidae), from the Paisley Caves site (Oregon, USA), with implications for prehistoric human ectoparasitism. J Archaeol Sci 116:105114

Aikens CM (1970) Hogup Cave. University of Utah Anthropological Papers 93

Aikens CM, Connolly TJ, Jenkins DL (2011) Oregon archaeology. Oregon State University Press, Corvallis

Albert RM, Weiner S (2001) Studies of phytoliths in prehistoric ash Layersfrom Kebara and Tabun caves using a quantitative approach. In: Dominique Meunier J, Colin F (eds) Phytoliths: applications in earth sciences and human history. AA Balkema, Lisse, pp 251-266

Alvarez WC, Freedlander BL (1924) The rate of progress of food residues through the bowel. J Am Med Assoc 83:576-580 
Andrews P (1990) Owls, caves, and fossils: predation, preservation, and accumulation of small mammal bones in caves, with an analysis of the Pleistocene cave faunas from Westbury-sub-Mendip, Somerset, UK. University of Chicago Press, Chicago

Battillo J (2019) Farmers who forage: interpreting paleofecal evidence of wild resource use by early corn farmers in the North American Southwest. Archaeol Anthropol Sci 11:5999-6016. https://doi.org/ 10.1007/s12520-019-00944-y

Beck C, Jones GT (1997) The terminal Pleistocene/Early Holocene archaeology of the Great Basin. J World Prehist 11:161-236. https:// doi.org/10.1007/BF02221204

Beck C, Jones GT (2013) Complexities of the colonization process: a view from the North American West. In: Graf KE, Ketron CV, Waters MR (eds) Paleoamerican odyssey. Texas A\&M University Press, College Station, pp 273-291

Beck CW, Bryant VM, Jenkins DL (2018) Analysis of Younger DryasEarly Holocene pollen in sediments of Paisley Cave 2, south-central Oregon. Palynology 42:168-179. https://doi.org/10.1080/ 01916122.2017.1319883

Beck CW, Bryant VM, McDonough KN (2019) Evidence for nonrandom distribution of pollen in human coprolites. Archaeol Anthropol Sci 11:5983-5998. https://doi.org/10.1007/s12520-01900839-y

Bedwell SF (1973) Fort Rock Basin prehistory and environment. University of Oregon Books, Eugene

Beers EH, Burts EC, Van Steenwyk RA (1993) Tenlined June beetle. In: Beers EH, Brunner JF, Willet MJ, Warner GM (eds) Orchard pest management: a resource for the Pacific Northwest. Washington State University Tree Fruit Research, Yakima

Benninghoff WS (1962) Calculation of pollen and spore density in sediments by addition of exotic pollen in known amounts. Pollen Spores 4:332

Birks HH (2007) Plant macrofossil introduction. In: Elias SA, Mock CJ (eds) Encyclopedia of Quaternary science, vol 2nd edition. Elsevier, pp 2266-2288

Blinnikov MS (2005) Phytoliths in plants and soils of the interior Pacific Northwest, USA. Rev Palaeobot Palynol 135:71-98. https://doi.org/ 10.1016/j.revpalbo.2005.02.006

Bousquet Y, Thomas DB, Bouchard P, Smith AD, Aalbu RL, Johnston MA, Steiner WE (2018) Catalogue of Tenebrionidae (Coleoptera) of North America. ZooKeys 728:1-455. https://doi.org/10.3897/ zookeys. 728.20602

Bradley BA, Collins MB, Hemmings A (2010) Clovis technology. International Monographs in Prehistory, Ann Arbor

Bronk Ramsey C (2013) OxCal v4.2.4. https://c14.arch.ox.ac.uk

Bryan AL (1980) The stemmed point tradition: an early technological tradition in Western North America. In: Harten LB, Warren CN, Tuohy DR (eds) Anthropological papers in memory of Earl H. Swanson, Jr., edited special publication of the Idaho Museum of Natural History, Pocatello, pp 77-107

Bryant VM (1974a) Pollen analysis of prehistoric human feces from mammoth cave. In: Watson PJ (ed) Archaeology of the mammoth cave area. Academic, Cambridge, pp 203-249

Bryant VM (1974b) Prehistoric diet in Southwest Texas: the coprolite evidence. Am Antiq 39(3):407-420

Bryant VM, Holloway RG (1983) The role of palynology in archaeology. Adv Archaeol Method Theory 6:191-224

Bryant VM, Hall SA (1993) Archaeological palynology in the United States: a critique. Am Antiq 58:277-286

Butler VL, Schroeder RA (1998) Do digestive processes leave diagnostic traces on fish bones? J Archaeol Sci 25:957-971. https://doi.org/10. 1006/jasc. 1997.0725

Callen EO (1963) Diet as revealed by coprolites. In: Brothwell D, Higgs E, Clark G (eds) Science in archaeology: a comprehensive survey of progress and research. Thames and Hudson, Bristol
Callen EO, Cameron TW (1960) A prehistoric diet revealed in coprolites. New Sci 8(190):35-40

Callen EO, Martin PS (1969) Plant remains in some coprolites from Utah. Am Antiq 34:329-331. https://doi.org/10.2307/278417

Cannon MD, Meltzer DJ (2004) Early Paleoindian foraging: examining the faunal evidence for large mammal specialization and regional variability in prey choice. Quat Sci Rev 23:1955-1987

Cannon MD, Meltzer DJ (2008) Explaining variability in Early Paleoindian foraging. Quat Int 191:5-17

Chame M (2003) Terrestrial mammal feces: a morphometric summary and description. Mem Inst Oswaldo Cruz 98:71-94

Collins MB (1999) Clovis blade technology: a comparative study of the Keven Davis cache. Texas archaeology and Ehtnohistory series. University of Texas Press, Austin

Connolly TJ, Jenkins DL (1999) The Paulina Lake site (35DS34). In: Connolly TJ (ed) Newberry crater: a ten-thousand-year record of human occupation and environmental change in the basin-plateau borderlands, vol 121. University of Utah Anthropological Papers, Salt Lake City, pp 86-127

Cummings LS, Yost C, Puseman K, Hill DV, Varney RA (2007) Microscopic and chemical evaluation of three coprolites from the Paisley 5 Mile Point Caves, Oregon. Paleo Research Institute Technical Report 07-91. Paleo Research Institute, Inc., Golden, Colorado

Davis MB (1966) Determination of absolute pollen frequency. Ecology 47:310-311

Davis LG, Willis SC, Macfarlan SJ (2012) Lithic technology, cultural transmission, and the nature of the Far Western Paleoarchaic/ Paleoindian co-tradition. In: Rhode D (ed) Meetings at the margins: prehistoric cultural interactions in the Intermountain West. University of Utah Press, Salt Lake City, pp 47-64

Davis LG et al (2019) Late Upper Paleolithic occupation at Cooper's Ferry, Idaho, USA, 16,000 years ago. Science (New York, NY) 365:891-897. https://doi.org/10.1126/science.aax9830

Dean G (1993) Use of pollen concentrations in coprolite analysis: an archaeobotanical viewpoint with a comment to Reinhard et al. 1991. J Ethnobiol 13:102-114

Doyen JT (1984) Systematics of Eusattus and Conisattus (Coleoptera; Tenebrionidae; Coniontini; Eusatti) vol 141

Driver JC (2011) Identification, classification and zooarchaeology. Ethnobiology Letters 2:19-39

Duke D (2015) Haskett spear weaponry and protein-residue evidence of proboscidean hunting in the Great Salt Lake Desert, Utah. PaleoAmerica 1:109-112

Ebeling W (1986) Handbook of Indian foods and fibers of arid America. University of California Press, Berkeley

Elston RG, Zeanah DW (2002) Thinking outside the box: a new perspective on diet breadth and sexual division of labor in the Prearchaic Great Basin. World Archaeol 34(1):103-130

Elston RG, Zeanah DW, Codding BF (2014) Living outside the box: an updated perspective on diet breadth and sexual division of labor in the Prearchaic Great Basin. Quat Int 352:200-211. https://doi.org/ 10.1016/j.quaint.2014.09.064

Erdtman G (1960) The acetolysis method: a revised description. Sven Bot Tidskr 54:561-564

Erlandson JM, Braje TJ, Gill KM, Graham MH (2015) Ecology of the kelp highway: did marine resources facilitate human dispersal from Northeast Asia to the Americas? J Island Coastal Archaeol 10(3): 392-411

Faegri K, Iversen J (1989) Textbook of pollen analysis, 4th edn. Wiley, Chichester

Faulkner CT (1991) Prehistoric diet and parasitic infection in Tennessee: evidence from the analysis of desiccated human paleofeces. Am Antiq 56:687-700. https://doi.org/10.2307/281546

Fisher BL, Cover SP (2007) Ants of North America. University of California Press, Berkeley 
Fisher JW Jr (1995) Bone surface modifications in zooarchaeology. J Archaeol Method Theor 2(1):7-68

Fowler CS (1986) Subsistence. In: Sturtevant WC, D’Azevedo WL (eds) Handbook of North American Indians Volume 11: Great Basin. Smithsonian Institution, Washington, D.C., pp 64-97

Fry GR (1970) Prehistoric human ecology in Utah: based on the analysis of coprolites. Dissertation, University of Utah

Fry GF (1976) Analysis of prehistoric coprolites from Utah. University of Utah Anthropological Papers 97, Salt Lake City

Fry GF (1978) Prehistoric diet at Danger Cave, Utah, as determined by the analysis of coprolites. University of Utah Anthropological Papers 99, Salt Lake City

Gilbert MTP, Jenkins DL, Götherstrom A, Naveran AN, Sanchez JJ, Hofreiter M, Thomsen PF, Binladen J, Higham TFG, Yohe RM, Parr R, Cummings LS, Willerslev E (2008) DNA from pre-Clovis human coprolites in Oregon, North America. Science 320(5877): 786-789

Gobalet KW (2001) A critique of faunal analysis; inconsistency among experts in blind tests. J Archaeol Sci 28(4):377-386

Goebel T, Keene J (2014) Are Great Basin stemmed points as old as Clovis in the Intermountain West? A review of geochronological evidence. In: Parezo NJ, Janetski J (eds) Archaeology in the Great Basin and Southwest. University of Utah Press, Salt Lake City, pp $35-60$

Goebel T, Hockett B, Adams KD, Rhode D, Graf K (2011) Climate, environment, and humans in North America's Great Basin during the Younger Dryas, 12,900-11,600 calendar years ago. Quat Int 242:479-501. https://doi.org/10.1016/j.quaint.2011.03.043

Graf KE (2001) Paleoindian technological provisioning. University of Nevada Las Vegas

Grayson DK (1984) Quantitative zooarchaeology: topics in the analysis of archaeological faunas. Academic, Orlando

Grayson DK (1988) Danger Cave, Last Supper Cave, and Hanging Rock Shelter: the faunas. Anthropological papers 66(1). American Museum of Natural History, New York

Grayson D (2011) The Great Basin: a natural prehistory. University of California Press, Berkeley

Harper KT, Alder GM (1970) The macroscopic plant remains of the deposits of Hogup Cave, Utah, and their paleoclimatic implications. In Aikens M (ed) Hogup Cave. University of Utah anthropological papers. 93. University of Utah Press, Salt Lake City. 215-240

Harvey EL, Fuller DQ (2005) Investigating crop processing using phytolith analysis: the example of rice and millets. J Archaeol Sci 32: 739-752. https://doi.org/10.1016/j.jas.2004.12.010

Haynes G (2002) The early settlement of North America: the Clovis era. Cambridge University Press, Cambridge

Haynes CV Jr (1966) Elephant-hunting in North America. Sci Am 214: 104-112

Hebard M (1916) A study of the species of the genus Stenopelmatus found in the United States. J New York Entomol Soc 24:70-86

Herzog NM, Lawlor AT (2016) Reevaluating diet and technology in the Archaic Great Basin using starch grain assemblages from Hogup Cave, Utah. Am Antiq 81(4):664-681

Hesse M, Waha M (1989) A new look at the acetolysis method. Plant Syst Evol 163:147-152. https://doi.org/10.1007/BF00936510

Hockett B (2007) Nutritional ecology of late Pleistocene to middle Holocene subsistence in the Great Basin: zooarchaeological evidence from Bonneville Estates Rockshelter. In: Graf KE, Schmitt DN (eds) Paleoindian or Paleoarchaic? Great Basin human ecology at the Pleistocene-Holocene transition. University of Utah Press, Salt Lake City, pp 204-230

Hockett B (2015) The zooarchaeology of Bonneville Estates Rockshelter: 13,000 years of Great Basin hunting strategies. J Archaeol Sci Rep 2:291-301
Hockett B, Jenkins DL (2013) Identifying stone tool cut marks and the pre-Clovis occupation of the Paisley Caves. Am Antiq 78:762-778. https://doi.org/10.7183/0002-7316.78.4.762

Hockett B, Adams ME, Lubinski PM, Butler VL, Jenkins DL (2017) Late Pleistocene subsistence in the Great Basin: Younger Dryas-aged faunal remains from the botanical Lens, Paisley Cave 2, Oregon. J Archaeol Sci Rep 13:565-576. https://doi.org/10.1016/j.jasrep. 2017.05.003

Jenkins DL (2007) Distribution and dating of cultural and paleontological remains at the Paisley Five Mile Point Caves in the northern Great Basin. In: Graf KE, Schmitt DN (eds) Paleoindian or Paleoarchaic? Great Basin human ecology at the Pleistocene/Holocene transition. The University of Utah Press, Salt Lake City, pp 57-81

Jenkins DL et al (2012) Clovis age western stemmed projectile points and human coprolites at the Paisley Caves. Science (New York, NY) 337:223-228. https://doi.org/10.1126/science.1218443

Jenkins DL et al (2013) Geochronology, archaeological context, and DNA at the Paisley Caves. In: Graf KE, Ketron CV, Waters MR (eds) Paleoamerican odyssey, vol 32. Texas A\&M University Press, College Station, pp 485-510

Jenkins DL et al (2016) Younger Dryas archaeology and human experience at the Paisley Caves in the northern Great Basin. In: Kornfeld M, Huckell BB (eds) Stones, bones, and profiles, exploring archaeological context, early American hunter-gatherers, and bison. University Press of Colorado, Boulder, pp 127-205

Jennings JD (1957) Danger Cave. University of Utah Anthropological Papers 27, Salt Lake City

Jones GT, Beck C, Jones EE, Hughes RE (2003) Lithic source use and Paleoarchaic foraging territories in the Great Basin. Am Antiq 68:538

Jones GT, Fontes LM, Horowitz RA, Beck C, Bailey DG (2012) Reconsidering Paleoarchaic mobility in the central Great Basin. Am Antiq 77(2):351-367

Jouy-Avantin F, Debenath A, Moigne AM, Mone' H (2003) A standardized method for the description and study of coprolites. J Archaeol Sci 30(3):367-372

Juggins S (2007) Version 1.5 user guide. Software for ecological and palaeoecological data analysis and visualisation. Newcastle University, Newcastle upon Tyne

Kapp RO, Davis OK, King JE (2000) Pollen and spores. The American Association of Stratigraphic Palynologists Inc (AASP), College Station

Kelly IT (1932) Ethnography of the Suprise Valley Paiute. Univ Calif Publ Am Archaeol Ethnol 31:67-210

Kelly RL, Todd LC (1988) Coming into the country: early Paleoindian hunting and mobility. Am Antiq 53:231-244

Kennedy JL (2018) A paleoethnobotanical approach to 14,000 years of Great Basin prehistory: assessing human-environmental interactions through the analysis of archaeological plant data at two Oregon rockshelters. University of Oregon

Kennedy JL, Smith GM (2016) Paleoethnobotany at the LSP-1 rockshelter, south central Oregon: assessing the nutritional diversity of plant foods in Holocene diet. J Archaeol Sci Rep 5:640-648

Lyman RL (2008) Quantitative paleozoology. Cambridge University Press, Cambridge

Madsen D (2007) The Paleoarchaic to Archaic transition in the Great Basin. In: Graf KE, Schmitt DN (eds) Paleoindian or Paleoarchaic? Great Basin human ecology at the Pleistocene/ Holocene transition. University of Utah Press, Salt Lake City, pp $3-20$

Madsen DB, Schmitt DN, Page D (2015) Introduction and research perspectives. In: Madsen DB, Schmitt DN, Page D (eds) The Paleoarchaic occupation of the Old River Bed Delta, 128th edn. University of Utah Anthropological Papers, Salt Lake City, pp 1-21

Maher LJ (1981) Statistics for microfossil concentration measurements employing samples spiked with marker grains. Rev Palaeobot 
Palynol 32:153-191. https://doi.org/10.1016/0034-6667(81)900026

Märkle T, Rösch M (2008) Experiments on the effects of carbonization on some cultivated plant seeds. Veg Hist Archaeobotany 17(S1): S257-S263. https://doi.org/10.1007/s00334-008-0165-7

Martin PS (1963) The last 10,000 years: a fossil pollen record of the American southwest. University of Arizona Press, Tuscon

Martin PS, Sharrock FW (1964) Pollen analysis of prehistoric human feces: a new approach to ethnobotany. Am Antiq 30(2):168-180

McDonough KN (2019) Middle Holocene menus: dietary reconstruction from coprolites at the Connley Caves, Oregon, USA. Archaeol Anthropol Sci 11:5963-5982. https://doi.org/10.1007/s12520-01900828-1

Middleton ES, Smith GM, Cannon WJ, Ricks MF (2014) Paleoindian rock art: establishing the antiquity of Great Basin carved abstract petroglyphs in the northern Great Basin. J Archaeol Sci 43:21-30. https://doi.org/10.1016/j.jas.2013.12.006

Milner N (1999) Pitfalls and problems in analysing and interpreting the seasonality of faunal remains. Archaeol Rev Cambridge 16:51-67

Minckley TA, Bartlein PJ, Shinker JJ (2004) Paleoecological response to climate change in the Great Basin since the Last Glacial Maximum. In: Jenkins DL, Connolly TJ, Aikens CM (eds) Early and Middle Holocene archaeology of the northern Great Basin, vol University of Oregon Anthropological Papers 62. University of Oregon, Eugene, pp 21-30

Monks GG (1981) Seasonality studies. In: Schiffer MB (ed) Advances in archaeological method and theory. Academic, San Diego, pp 177 240. https://doi.org/10.1016/B978-0-12-003104-7.50009-0

Moore PD, Webb JA, Collison ME (1991) Pollen analysis. Blackwell Scientific

Morris LR, Baker FA, Morris C, Ryel RJ (2009) Phytolith types and typefrequencies in native and introduced species of the sagebrush steppe and pinyon-juniper woodlands of the Great Basin, USA. Rev Palaeobot Palynol 157(3-4):339-357

Napton LK (1997) The Spirit Cave mummy. Nevada Hist Soc Q 40:97104

Nomland GA (1938) Bear River ethnography. Anthropological records Vol 2. University of California Press, Oakland

O'Meara DP (2014) Ruminating on the past. A history of digestive Taphonomy in experimental archaeology. In: Flores JR, Paardekooper R (eds) Experiments past: histories of experimental archaeology. Sidestone Press, Leiden, pp 131-146

Page LM et al. (2013) Common and scientific names of fishes from the United States, Canada, and Mexico vol 34. American Fisheries Society, Bethesda

Parmalee PW (1988) Avian remains from Danger Cave. Danger Cave, Last Supper Cave, and hanging rock shelter: the faunas. Anthropol Pap Am Museum Nat Hist Part 1:37-43

Pearsall DM (2015) Paleoethnobotany: a handbook of procedures. Left Coast Press, Walnut Creek

Piperno DR (1988) Phytolith analysis: an archaeological and geological perspective. Academic, San Diego

Rasmussen SO, Bigler M, Blockley SP, Blunier T, Buchardt SL, Clausen HB, Cvijanovic I, Dahl-Jensen D, Johnsen SJ, Fischer H, Gkinis V, Guillevic M, Hoek WZ, Lowe JJ, Pedro JB, Popp T, Seierstad IK, Steffensen JP, Svensson AM, Vallelonga P, Vinther BM, Walker MJC, Wheatley JJ, Winstrup M (2014) A stratigraphic framework for abrupt climatic changes during the last glacial period based on three synchronized Greenland ice-core records: refining and extending the INTIMATE event stratigraphy. Quat Sci Rev 106:14-28. https://doi.org/10.1016/j.quascirev.2014.09.007

Reimer PJ, Bard E, Bayliss A, Beck JW, Blackwell PG, Ramsey CB, Buck CE, Cheng H, Edwards RL, Friedrich M, Grootes PM (2013) IntCal13 and Marine13 radiocarbon age calibration curves 0-50,000 years cal BP. Radiocarbon 55(4):1869-1887
Reinhard KJ (1993) The utility of pollen concentration in coprolite analysis: expanding upon Dean's comments. J Ethnobiol 13:114-128

Reinhard KJ, Bryant VM (1992) Coprolite analysis: a biological perspective on archaeology. Archaeol Method Theory 4:245-288

Reinhard KJ, Bryant VM (2008) Pathoecology and the future of coprolite studies in bioarchaeology. In: Stodder ALW (ed) Reanalysis and reinterpretation in southwestern bioarcheology, Arizona State University anthropological research papers, Tuscon, p 59

Reinhard KJ, Hamilton DL, Hevly RH (1991) Use of pollen concentration in paleopharmacology: coprolite evidence of medicinal plants. J Ethnobiol 11:117-132

Reinhard KJ, Ambler JR, Szuter CR (2007) Hunter-gatherer use of small animal food resources: coprolite evidence. Int J Osteoarchaeol 17: 416-428. https://doi.org/10.1002/oa.883

Rhode D, Louderback LA (2007) Dietary plant use in the Bonneville basin during the terminal Pleistocene/early Holocene transition. In: Graf KE, Schmitt DN (eds) Paleoindian or Paleoarchaic? Great Basin human ecology at the Pleistocene-Holocene transition. University of Utah Press, Salt Lake City, pp 231-247

Rhode D, Madsen DB, Jones KT (2006) Antiquity of early Holocene small-seed consumption and processing at Danger Cave. Antiquity 80:328-339

Ricks MF, Cannon WJ (1993) A preliminary report on the Lake County, Oregon, rock art inventory: a data base for rock art research. In: Hyder WD (ed) American Indian rock art: papers presented at the rock art symposium. American Rock Art Research Association, San Miguel, pp 93-106

Riley TE (2008) Diet and seasonality in the Lower Pecos: evaluating coprolite data sets with cluster analysis. J Archaeol Sci 35:27262741. https://doi.org/10.1016/j.jas.2008.04.022

Riley TE (2010) Assessing diet and seasonality in the lower Pecos Canyonlands: an evaluation of coprolite specimens as records of individual dietary decisions. Texas A\&M University

Saban CV (2015) Palynological perspectives on Younger Dryas to Early Holocene human ecology at Paisley Caves. Oregon State University, Oregon

Saban CV, Jenkins DL (2013) Late Pleistocene to Early Holocene paleoenvironmental conditions at Paisley Caves (35LK3400), cave 2. Curr Archaeol Happenings Oregon 38:20-24

Sauqué V, Sanchis A, Madurell-Malapeira J (2018) Late Pleistocene leopards as a bone accumulator: taphonomic results from S'Espasa cave and other Iberian key sites. Hist Biol 30:821-834. https://doi. org/10.1080/08912963.2017.1343313

Sharma N, Koul P, Koul AK (1993) Pollination biology of some species of genus Plantago L. Bot J Linn Soc 111:129-138. https://doi.org/ 10.1111/j.1095-8339.1993.tb01895.x

Shillito L-M, Bull ID, Matthews W, Almond MJ, Williams JM, Evershed RP (2011) Biomolecular and micromorphological analysis of suspected faecal deposits at Neolithic Çatalhöyük. Turkey J Archaeol Sci 38:1869-1877. https://doi.org/10.1016/j.jas.2011.03. 031

Shillito L-M, Blong JC, Jenkins DL, Stafford TW, Whelton H, McDonough K, Bull ID (2018) New research at Paisley Caves: applying new integrated analytical approaches to understanding stratigraphy, taphonomy, and site formation processes. PaleoAmerica 4:82-86. https://doi.org/10.1080/20555563.2017. 1396167

Shillito L-M, Blong JC, Green EJ, van Asperen EN (2020a) The what, how and why of archaeological coprolite analysis. Earth Sci Rev, published online. https://doi.org/10.1016/j.earscirev.2020.103196

Shillito L-M, Whelton H, Blong JC, Jenkins DL, Connolly TC, Bull ID (2020b) Pre-Clovis occupation of the Americas identified by human faecal biomarkers in coprolites from Paisley Caves, Oregon. Science Advances 6:eaba6404

Simms S (2008) Ancient peoples of the Great Basin and Colorado plateau. Routledge, New York 
Smith GM (2010) Footprints across the black rock: temporal variability in prehistoric foraging territories and toolstone procurement strategies in the Western Great Basin. Am Antiq 75:865-885

Smith GM (2011) Shifting stones and changing homes: using toolstone ratios to consider relative occupation span in the northwestern Great Basin. J Archaeol Sci 38:461-469

Smith GM, Barker P (2017) The terminal Pleistocene/Early Holocene record in the northwestern Great Basin: what we know, what we don't know, and how we may be wrong. Paleoamerica 3(1):13-47

Smith GM et al. (2020) The Western stemmed tradition: problems and prospects in Paleoindian archaeology in the Intermountain West. PaleoAmerica:1-20 doi:https://doi.org/10.1080/20555563.2019. 1653153

Sobolik KD (1988) The importance of pollen concentration values from coprolites: an analysis of Southwest Texas samples. Palynology 12: 201-214. https://doi.org/10.1080/01916122.1988.9989344

Stockmarr J (1971) Tablets with spores used in absolute pollen analysis. Pollen et spores

Surovell TA, Waguespack N (2008) How many elephant kills are 14? Clovis mammoth and mastodon kills in context. Quat Int 191:82-97

Sutton MQ (1988) Insects as food: aboriginal entomophagy in the Great Basin. Ballena Press, Menlo Park

Sutton M (1995) Archaeological aspects of insect use. J Archaeol Method Theory 2:253-298. https://doi.org/10.1007/BF02229009

Taylor A, Hutson JM, Bryant VM, Jenkins DL (2019) Dietary items in early to Late Holocene human coprolites from Paisley Caves, Oregon, USA. Palynology 44(1):12-23
Twiss PC, Suess E, Smith RM (1969) Morphological classification of grass phytoliths. Soil Sci Soc Am J 33:109-115

Waguespack NM, Surovell TA (2003) Clovis hunting strategies, or how to make out on plentiful resources. Am Antiq 68(2):333-352

Waters MR, Stafford TW Jr (2007) Redefining the age of Clovis: implications for the peopling of the Americas. Science 315:1122-1126

Waters MR, Forman SL, Jennings TA, Nordt LC, Driese SG, Feinberg JM, Keene JL, Halligan J, Lindquist A, Pierson J, Hallmark CT, Collins MB, Wiederhold JE (2011) The Buttermilk Creek complex and the origins of Clovis at the Debra L. Friedkin site, Texas. Science 331:1599-1603

Waters MR, Keene JL, Forman SL, Prewitt ER, Carlson DL, Wiederhold JE (2018) Pre-Clovis projectile points at the Debra L. Friedkin site, Texas-implications for the Late Pleistocene peopling of the Americas. Sci Adv 4(10):eaat4505

Wyman LC, Bailey FL (1964) Navaho Indian ethnoentomology. University of New Mexico Press, Albuquerque

Young RM (1988) A monograph of the genus Polyphylla Harris in American north of Mexico (Coleoptera: Scarabaeidae: Melolontinae) Bulletin of the University of Nebraska State Museum

Publisher's note Springer Nature remains neutral with regard to jurisdictional claims in published maps and institutional affiliations. 